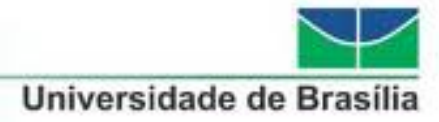

Instituto de Ciência Política

\title{
O MINISTÉRIO PÚBLICO E ACCOUNTABILITY HORIZONTAL
}

BRUNO DE OLIVEIRA SANTOS PAIVA NOGUEIRA

Brasília

2011 


\section{BRUNO DE OLIVEIRA SANTOS PAIVA NOGUEIRA}

\section{O MINISTÉRIO PÚBLICO E ACCOUNTABILITY HORIZONTAL}

Monografia apresentada para a obtenção do grau de bacharel em Ciência Política na Universidade de Brasília.

Professora orientadora: Prof. ${ }^{a}$ Dr. ${ }^{a}$ Graziela Dias Teixeira

Examinadora: Prof. ${ }^{\text {a }}$ Dr. ${ }^{\text {a }}$ Marilde Loiola de Menezes

\section{Brasília}




\section{BRUNO DE OLIVEIRA SANTOS PAIVA NOGUEIRA}

\section{O MINISTÉRIO PÚBLICO E ACCOUNTABILITY HORIZONTAL}

Monografia de conclusão de curso submetida ao Instituto de Ciência

Política da Universidade de Brasília como requisito final para a obtenção do título de bacharel em Ciência Política, apresentada à seguinte banca examinadora.

Professora Graziela Dias Teixeira

(Universidade de Brasília)

Professora Marilde Loiola de Menezes

(Universidade de Brasília)

Brasília 


\section{AGRADECIMENTOS}

Gostaria de agradecer primeiramente a meus pais, Paulo e Margarete, por todo apoio que eles me dão e sempre deram a minhas escolhas. Fico muito feliz por tê-los ao meu lado em momentos de decisão. Também gostaria de agradecer a meus amigos e demais familiares, pois desta convivência sempre desenvolvi um grande aprendizado.

Agradeço também a todos os grandes professores que tive no Ensino Médio e durante o curso de graduação na UnB: ao professor Mattos, quem me despertou o interesse pela história e que sem ele eu talvez não tivesse cursado Ciência Política.

À professora Graziela, por ter sido uma excelente orientadora e guia, de nossas reuniões semanais em Pesquisa que surgiram as condições para a realização desta monografia. Aos professores Terrie Groth, José Donizeth, Paulo Calmon e Leonardo Barreto. Todos foram essenciais para minha formação, e com eles pude desenvolver meu caráter.

Por último agradeço a todas as grandes figuras da história, aos grandes filósofos e gênios excêntricos. Todas as pessoas que utilizam a criatividade como ferramenta de vida, e que apreciam a magia deste grande Mistério. 
"Não se coloque dentro de uma forma, se adapte e construa sua própria, e deixa-a expandir, como a água [...]

Se colocarmos a água num copo, ela se torna o copo; se você colocar água numa garrafa ela se torna a garrafa [...]. Água pode fluir ou pode colidir.

Seja água, meu amigo" 


\section{Resumo}

O objetivo deste trabalho é analisar o Ministério Público e seu posicionamento na estrutura da accountability política horizontal. Ele se divide em quatro partes. Na primeira, realizo um tratamento analítico ao conceito de accountability e sua conceitualização sob a ótica de diversos autores. Busco estabelecer uma fronteira semântica para possibilitar sua utilização como ferramenta de análise. Na segunda, relaciono sua aplicação para a política e sociedade brasileira, segundo o estudo de Campos no final dos anos oitenta e o estudo de Pinho e Sacramento, mais recente. Em seguida, foco no Ministério Público e utilizo o conceito para tentar entender sua inserção nesta instituição. Na última parte, o Conselho Nacional do Ministério Público é estudado para verificar possíveis melhoramentos na accountability.

\footnotetext{
Abstract

The main goal of this paper is to give an account of the Ministério Público's position in the structure of horizontal political accountability. It is divided into four parts. In the first one, I give an analytical approach to the concept of accountability and its conceptualization in the view of several authors. I seek to establish a semantic frontier in order to make its use as a tool of analysis possible. In the second part, I give an account of its use for the Brazilian context, political and socially, according to the studies of Campos in the end of the eighties and the recent paper of Pinho and Sacramento. Then I focus on the Ministério Público and use the concept to try to comprehend its insertion within the institution. In the last part, the Conselho Nacional do Ministério Público is studied to check for possible improvements in the accountability.
} 


\section{Sumário}

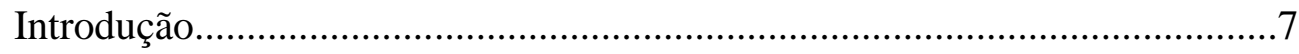

1. Conceitualizando Accountability ......................................... 10

1.1. O conceito nuclear.....................................................10

1.2. O conceito bidimensional.................................................12

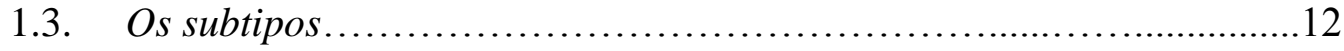

1.4. Direção espacial: o prisma vertical......................................14

1.5. Direção espacial: o prisma horizontal............................................14

1.6. O processo interativo da accountability horizontal...........................17

1.7. A accountability política ..........................................................18

2. Accountability no Brasil......................................................................20

2.1. A tradução para o português..........................................................20

2.2. O caminho para a tradução......................................................22

2.3. Accountability no Judiciário brasileiro...........................................25

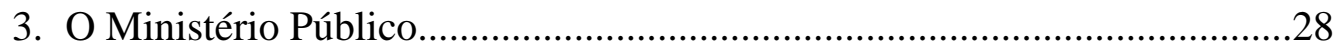

3.1. A importância do Ministério Público.................................................32

3.2. O Ministério Público como agência de Accountability (Principal)........33

3.3. O Ministério Público como agente de Accountability (Agent)...............39

3.3.1. O Conselho Nacional do Ministério Público.................................43

Conclusão 


\section{Introdução}

Para a formação dos Estados modernos, uma série de escolas de pensamento influenciou e continua influenciando nas buscas por uma resposta à clássica pergunta feita por Platão em $A$ República: "O que é bom para a cidade?” Os cientistas políticos estudam tais escolas e os diversos conceitos que derivam delas.

A teoria democrática na contemporaneidade é uma das mais tradicionais áreas de estudo da Ciência Política. Não requer muita imaginação sociológica para constatar que as diretrizes que norteiam o funcionamento dos Estados modernos do Ocidente são de caráter democrático. Com isso em mente, muitos cientistas políticos navegam nos estudos sobre a democracia, analisando o funcionamento do corpo político, comparando com a teoria e com as expectativas sociais. Uma problematização comum é como desenvolver a democracia. A teoria fornece uma série de ferramentas para confrontar esta questão.

O conceito de accountability surge como uma dessas ferramentas. Ele é bastante útil para o trabalho intelectual que visa se aprofundar nos estudos de democracias. Uma das premissas mais enraizadas em democracias atuais é que o poder político deve ser de alguma forma controlado. Esta idéia é trazida desde os teóricos políticos modernos, como Locke, Montesquieu e os Federalistas.

A conseqüência dessas idéias é que atualmente diversos órgãos compartilham o poder de Estado, que é controlado tanto por agentes estatais como por agentes não-estatais. A accountability é conceitualmente bastante útil para o estudo desse controle. No âmbito da accountability política, as diversas instituições do Estado podem tanto atuar como fiscalizadoras de outras, como também serem fiscalizadas. Lindberg (2009), ao conceitualizar a accountability, denomina os dois pólos - fiscalizador e fiscalizado - respectivamente de principal e agent.

No Brasil, os questionamentos levantados pela accountability são extremamente atuais. As críticas ao governo são comuns tanto na mídia quanto na opinião dos cidadãos. Um dos principais problemas relacionados à atuação de oficiais públicos diz respeito à sujeição à lei (O’DONNELL, 1998). Casos de corrupção são comuns nas páginas de jornal, e há uma sensação de 
impunidade. O desenvolvimento da accountability possibilita mitigar os delitos cometidos por agentes públicos.

Uma das instituições que recentemente adquiriu grande relevância no cenário político brasileiro é o Ministério Público. Sua posição no contexto sócio-político faz com que ele seja freqüentemente chamado de "quarto poder", portanto é pertinente estudá-lo tendo como medida a accountability.

Este trabalho buscará analisar o Ministério Público no âmbito da accountability política. O estudo será tanto de seu papel como agente fiscalizador dos outros agentes do Estado (principal), como também da sua posição como agente fiscalizado (agent): quem e como controla sua atuação.

Discussões acerca do Ministério Público estiveram presentes na cena política nacional e deram origem ao Conselho Nacional do Ministério Público em 2004. Um dos objetivos da criação do Conselho era desenvolver mecanismos para o controle do Ministério Público, logo seu estudo é de grande relevância para a accountability.

Através do desenvolvimento teórico de diversos estudiosos no prisma da accountability, com foco no trabalho de Staffan Lindberg, tentarei analisar as recentes dimensões que foram dadas ao Ministério Público e seu impacto na estrutura democrática do controle do poder político.

O trabalho está divido em quatro capítulos. No primeiro, busca-se uma melhor compreensão do conceito de accountability: é traçado um panorama de recentes trabalhos sobre o tema para esclarecer o sentido do conceito na sua posterior utilização. Em seguida, é feita uma análise da accountability no Brasil após a redemocratização. O Ministério Público possui grandes semelhanças com a configuração do Judiciário, e por esta razão dá-se um enfoque na accountability deste poder.

No terceiro capítulo procurei utilizar as ferramentas teóricas para analisar a accountability em relação ao Ministério Público. Primeiramente tracei um pequeno histórico da instituição e sua grande importância sócio-política, para em seguida analisá-lo como agent $e$ principal, destacando nesta parte, o Conselho Nacional do Ministério Público, instaurado recentemente, com um enfoque nas possíveis mudanças que ele traz no âmbito da accountability. 
Para a tarefa, foi utilizada uma série de estudos na ciência política sobre accountability e democracia, além da nova Constituição brasileira e suas disposições. Para o recorte histórico do Ministério Público no âmbito constitucional, pesquisei Constituições anteriores, além de um estudo feito pelo procurador Maurício Gomes. Para estudo do Conselho Nacional do Ministério Público, foi acessado o sítio eletrônico do órgão, bem como foram utilizados os dados obtidos em uma pesquisa realizada pelo Instituto de Ciência Política ${ }^{1}$.

Espera-se ao final do trabalho uma melhor compreensão do Ministério Público à luz da accountability, uma visualização das mudanças trazidas pelo Conselho e possibilitar uma perspectiva mais ampla: situar o Ministério Público em um contexto no qual a accountability de nossas instituições políticas está relacionada a práticas culturais e históricas.

${ }^{1}$ Esta pesquisa é fruto dos estudos realizados em 2010 sobre o Ministério Público sob a coordenação das professoras Marilde Loiola de Menezes e Graziela Dias Teixeira e com a participação de alunos de Graduação e Pós-Graduação em Ciência Política pela Universidade de Brasília. 


\section{Conceitualizando Accountability}

Com a ascensão dos valores liberal-democráticos na formação dos Estados modernos, o termo accountability se desenvolve como um conceito importante para analisar a atuação do setor público. A sociedade civil espera que os impostos sejam usados para favorecer a população da maneira mais eficiente possível. Altos custos da burocracia, desvios de verbas públicas para fins particulares (corrupção), morosidade decisória e decisões políticas visando interesses individuais e não os coletivos são malvistos pela sociedade e acabam prejudicando a imagem das instituições públicas. Governos que buscam uma boa governança tentam evitar tais vicissitudes.

De uma forma geral, é razoável considerar que a "boa governança” é uma vontade coletiva nas novas democracias. Governança no sentido da "maneira pela qual o poder é exercido na administração dos recursos sociais e econômicos de um país visando o desenvolvimento" (GONÇALVES, 2005). Na atualidade uma boa governança implica não somente em gastos eficientes dos recursos públicos, mas também se torna um fator crucial para o desenvolvimento econômico e social (SANTOS apud GONÇALVES, 2005).

O conceito de accountability se situa como uma das ferramentas existentes para averiguar a qualidade da governança. Nas ciências sociais contemporâneas, o termo se tornou bastante popular, levando a uma miríade de significações mais ou menos distintas. Pesquisando os termos "accountability" e "democracia", ou "accountability" e "América Latina" em bases de dados digitais, são encontrados inúmeros artigos sobre o assunto.

\subsection{0 conceito nuclear}

Staffan Lindberg busca em seu artigo "Accountability: the core concept and its subtypes" (2009) dar um tratamento analítico ao termo e definir a idéia nuclear e os diversos subtipos decorrentes desse núcleo. Ele afirma que há perigos no "estiramento conceitual", que podem levar a "ambigüidade, vagueza e confusão semântica coletiva" (ibidem, p. 2, tradução nossa). Sua argumentação é fundamentada na idéia de accountability como um dos vários métodos de controle do poder, este no sentido clássico tipológico (SARTORI apud LINDBERG, 2009, p. 2). 
Fundamentação semelhante pode ser encontrada em Schedler ao comentar sobre a opacidade do poder (1999, p. 20-21)

Na busca por uma definição nuclear, objetiva-se estabelecer um fundo-comum para a comunicação dos diversos trabalhos que utilizam o conceito. Nota-se uma relação bem próxima entre accountability, autoridade e democracia, pois: 1) segundo o princípio de Bentham, "Quanto mais bem vigiados somos nós, melhor nos comportamos" (HOOD et al apud LINDBERG, 2009, p.7, tradução nossa), o que remete ao princípio da separação dos poderes e da necessidade de controle; 2) "Como percebido por Nietzsche, só prestamos conta ou damos satisfações quando estas são solicitadas, e somente quando a solicitação está respaldada por poder" (BUTLER apud LINDBERG, 2009, p. 7, tradução nossa), sendo assim, "fundamentalmente a accountability está relacionada com autoridade, mas não necessariamente autoridade política" (LINDBERG, 2009, p.7, tradução nossa); 3) há uma necessidade de discricionariedade dos agentes, pois a idéia de controle está relacionada a possibilidade de desvios de conduta. Como afirma Schedler (1999, p.18), o princípio da accountability política é o controle do poder político, e não sua eliminação.

O conceito nuclear (chamado de conceito radial por Schedler) de accountability é descrito por Lindberg da seguinte maneira (2009, p. 8, tradução nossa):

1. Um agente ou instituição que deve dar satisfações ${ }^{2}$ (A para agent $^{3}$ );

2. Uma área, atribuições, ou um domínio sujeito a accountability (D para domínio);

3. Um agente ou instituição para quem A deve dar satisfações (P para principal);

4. O direito de $\mathrm{P}$ solicitar a A esclarecimentos e justificativas quanto a D;

5. $\mathrm{O}$ direito de $\mathrm{P}$ penalizar $\mathrm{A}$ se $\mathrm{A}$ falhar em esclarecer e/ou justificar decisões relacionadas a $\mathrm{D}$.

Essas cinco características são essenciais para a forma mais básica de accountability. Segundo Lindberg, elas estão presentes em maior ou menor nível. O autor busca uma abordagem mais genérica do termo, abrangendo não somente a esfera política, mas também a fiscal, a relação patrão-cliente, a "societal", etc. (cf. ibidem, p.11-14). É importante frisar que a característica cinco na sua essência se restringe ao direito de penalizar por falhar em fornecer esclarecimentos e

\footnotetext{
${ }^{2}$ No original, give an account.

${ }^{3}$ Doravante ao mencionar agents e principals, estarei me referindo a tais conceitos como dispostos por Lindberg (2009).
} 
justificativas, e não necessariamente se estende ao direito de punir devido ao conteúdo de tais informações (ibidem, p.9). É claro que caso não haja punições quanto ao conteúdo de $\mathrm{D}$, não haverá estímulo para o agente seguir a conduta que é esperada, sendo mais razoável ao estudar a esfera política incluir a punição dos desvios de conduta na característica cinco.

\section{$1.2 \mathrm{O}$ conceito bidimensional}

É também com o propósito de denotação do termo accountability que se situa o artigo de Schedler (1999). Ao contrário de Lindberg, sua abordagem se dirige mais à noção de accountability política, aquela voltada aos agentes públicos. Em uma conceitualização bidimensional, denotam-se as duas características que constituem a accountability - em inglês, aswerability e enforcement - que representam a necessidade de "dar explicações" e do poder da "coação legal” (RODRIGUES, 2008, p.28).

A dimensão da answerability representa a característica quatro do conceito núcleo descrito acima. Vale ressaltar que P pode solicitar para que A informe suas decisões, ou para que as justifique, correspondendo respectivamente ao âmbito informacional e ao âmbito argumentativo da accountability (Schedler, p.14).

A outra dimensão, correspondente ao poder de punição, remete à característica cinco do conceito núcleo. Ao contrário de Lindberg, muito autores, como Taylor e Buranelli (2007), O'Donnel (1998) e Rodrigues (2008) consideram parte essencial da accountability a capacidade de punir o desvios de conduta, e não somente as falhas no fornecimento de informações e justificativas. Quando se discute a necessidade de controle do poder na esfera política, a punição por más condutas é vital para que haja um sentido em buscar informações sobre a atuação dos agentes públicos. Como escreve Andreas Schedler: "a não ser que haja alguma punição para abusos de autoridade evidentes, não há império da lei e conseqüentemente accountability" (1999, p.17, tradução nossa).

\subsection{Os subtipos}

A partir do conceito-núcleo, Lindberg criou uma tipologia de 12 subtipos de accountability, classificados de acordo com critérios de intensidade (alta ou baixa), direção espacial 
(vertical ascendente ou descendente; horizontal) e se a fonte de controle é interna ou externa ao agente A (2009, p.12, tradução nossa):

Tabela 1 - Sub-tipos de accountability

\begin{tabular}{lcccc}
\hline Fonte de Controle & Intensidade de Controle & Vertical & Horizontal \\
& & Ascendente & Descendente & \\
\hline Interna & Alta & Empresa & Burocrática & Auditoria \\
& Baixa & Cliente-Patrono & Patrono-Cliente & Par Profissional \\
Externa & Alta & Representativa & Fiscal & Legal \\
& Baixa & Societal & Política & Reputacional \\
\hline
\end{tabular}

Esta tipologia é bastante interessante por permitir a investigação de diversos tipos diferentes de accountability em uma mesma organização. Há uma rede de interações profissionais entre indivíduos de dentro e de fora das organizações, que se constitui de múltiplas formas diferentes. Na esfera governamental, as interações formam diferentes tipos de accountability. Podemos identificar ao menos quatro padrões de interação possíveis ao estudar uma instituição do governo:

1. Tanto A e P são internos à instituição.

2. P é externo à instituição, mas de uma instituição pertencente ao mesmo Poder.

3. P é externo à instituição e de um Poder diferente.

4. P faz parte da sociedade civil (é externa à esfera governamental).

A tipologia de Lindberg, ao incluir o critério de direção espacial, remete ao trabalho de O’Donnel (1998). A distinção entre accountability horizontal e vertical fornece benefícios heurísticos substantivos. Deve-se ter em mente a metáfora da pirâmide hierárquica, onde aqueles mais acima possuem maior poder. 


\subsection{Direção espacial: o prisma vertical}

A dimensão vertical se refere uma relação entre "desiguais". Um exemplo clássico são as eleições: os eleitores têm a oportunidade de punir políticos devido a uma má atuação, não votando neles, e também podem premiar aqueles que exerceram um bom mandato, reelegendo-os (ou votando no mesmo partido). Esse exemplo caracteriza uma accountability vertical ascendente: aqueles com menor poder (no sentido de influência decisória) são os principals, enquanto os mais poderosos são os agents. Na política, existem outras maneiras da sociedade civil exercer uma accountability dos agentes políticos, principalmente por meio de mecanismos midiáticos que influenciam a opinião pública. No entanto, tais mecanismos são bem difusos e a possibilidade de sanção per se é quase nula. Lindberg chama esse tipo de accountability societal (2009, p.14).

Smulovitz e Peruzzotti (2003) consideram o controle societal como vital para a manutenção das outras formas de controle (como o eleitoral e o horizontal, de acordo com a definição de O’Donnell). Os autores o definem como uma forma vertical não-eleitoral de accountability, que possibilita o controle político pelos cidadãos entre as eleições. As "agências de accountability societal" (mídia, organizações sociais, indivíduos) trabalhariam 1) expondo e denunciando delitos descobertos; 2) acionando os mecanismos de controle horizontal do Estado, seja pela demanda dos movimentos sociais, pela ação midiática, ou pela litigiosidade; 3) pela supervisão constante de órgãos públicos específicos, sendo os "guardiões dos guardiões". Cabe ressaltar que vários autores, como Lindberg (2009), Mainwaring (2003), O’Donnell (1998) e Schedler (1999), minimizam a importância da accountability societal devido a seu caráter difuso e à prevalência do Estado no processo decisório político.

Na direção vertical, sentido descendente, há o exemplo dos oficiais do Executivo de alto escalão que nomeiam cargos para os ministérios. Em última instância, a cúpula presidencial é a responsável pela atuação dos oficiais dos ministérios, pois será julgada pela atuação do Executivo como um todo durante as eleições. Existe accountability burocrática (LINDBERG, 2009, p.12, tradução nossa) na interação do núcleo do Executivo com os ministros de Estado.

\subsection{Direção espacial: o prisma horizontal}

Em governos democráticos é a dimensão horizontal que possui maior importância para a manutenção dos princípios da democracia. A divisão dos poderes na teoria democrática - em 
Executivo, Legislativo e Judiciário, e o sistema de pesos e contrapesos no qual cada poder regula os outros - é uma expressão arcaica da accountability horizontal. (SCHEDLER, 1999, p. 23).

Para Guillermo O’Donnell (1998, p.40) accountability horizontal define-se como:

A existência de agências estatais que têm o direito e o poder legal e que estão de fato dispostas e capacitadas para realizar ações, que vão desde a supervisão de rotina a sanções legais ou até o impeachment contra ações ou emissões de outros agentes ou agências do Estado que possam ser qualificadas como delituosas.

O fato de tais agências possuírem direito e poder legal para exercer a accountability não implica que elas possuam "nível de poder" equivalente ao das instituições controladas. Se a accountability vertical dispõe uma relação "entre desiguais" e a dimensão horizontal reflete uma relação "entre iguais", é no sentido do nível de discricionariedade que os envolvidos possuem para exercer a accountability entre eles. (SCHEDLER, 1999, p. 24)

Existem controvérsias quanto à amplitude da dimensão horizontal. O’Donnell (1998) limita o termo a relações intraestado. Philippe Schmitter (1999) e Richard Sklar(1999) consideram que agentes não-estatais podem exercer accountability horizontal ${ }^{4}$. Schedler dispõe que as associações civis (1999, p.25, tradução nossa)

nunca podem igualar o monopólio do uso legítimo da força do Estado, ou sua posição privilegiada como fonte da lei - de regras uniformes, centralmente definidas e de escopo coletivo. Portanto, falar de relações horizontais entre as duas esferas $^{5}$ sempre soa algo como um eufemismo

Com isso em mente é razoável limitar a accountability horizontal de agents do Estado a principals também estatais. No caso de principals da sociedade civil, a assimetria expõe a verticalidade da accountability.

A definição de O’Donnell dispõe uma relação entre A e P externos (não-pertencentes à mesma agência). No entanto Lindberg afirma que agentes internos podem exercer accountability horizontal de seus pares (2009, p.12). Várias instituições públicas possuem departamentos responsáveis pelo controle administrativo dos gastos (responsáveis por auditar), além de ouvidorias para receber reclamações. 
Os companheiros de profissão também realizam um tipo de accountability. Há um controle difuso uma vez que os pares "podem apenas solicitar informações não-específicas, sobre segmentos estreitos da atuação de seus colegas" (ibidem, p.13). O foco é a manutenção da reputação da organização ou da profissão.

Sobre as agências descritas por O’Donnell, é importante ressaltar que elas não atuam de maneira isolada. Como o autor afirma (1998, p.43-44):

A accountability horizontal efetiva não é o produto de agências isoladas mas de redes de agências que têm em seu cume, porque é ali que o sistema constitucional "se fecha" mediante decisões últimas, tribunais (incluindo os mais elevados) comprometidos com essa accountability. (...) a sabedoria dos Federalistas levou não à divisão um tanto mecânica de poderes proposta por seus oponentes mas a instituições que parcialmente se superpõem em sua autoridade. Isso produziu um arranjo que, criando diversos poderes fortes que parcialmente interferem um no outro, aumentou a autonomia de cada um deles com respeito à que teria resultado de uma separação simples desses poderes.

A superposição de poderes tornou-se critério normativo para a boa governança, pois na teoria democrática "todo poder deve ser controlado, ou haverá abusos". Com isso em mente, quem fiscaliza os agentes fiscalizadores? Como sugere Rodrigues (2008, p.42)

Uma possibilidade é através de accountability recíproca, em que dois agentes, A e B fiscalizam um ao outro. Uma outra possibilidade é uma accountability recursiva, em que A fiscaliza B, que fiscaliza C, que fiscaliza A. É difícil imaginar tal situação na prática, mas para se alcançar um grau elevado de accountability é necessário a existência de várias agências estatais ligadas entre si.

O’Donnell coloca que o propósito da accountability horizontal seria evitar ou minimizar o efeito de ações e emissões consideradas delituosas. Em democracias consolidadas (ou poliarquias), a maior preocupação é com a atuação de autoridades em geral bem posicionadas no Estado ou no regime, podendo ter sido ou não eleitas. O delito nesse caso se caracteriza por um abuso dessas autoridades, quando não se sujeitam de maneira adequada à lei ou quando priorizam interesses particulares em detrimento do dever público. (1998, p. 41)

Um dos propósitos da accountability horizontal seria evitar o crime da prevaricação, como descrito no Artigo 319 do Código Penal: "Retardar ou deixar de praticar, indevidamente, ato

\footnotetext{
${ }^{4}$ Schmitter considera que atores não-estatais como grandes empresas capitalistas, partidos políticos, juntas comerciais, movimentos sociais e a mídia podem servir como agências de accountability horizontal. Sklar considera a inclusão de instituições como as organizações de saúde e universidades.
} 
de ofício, ou praticá-lo contra disposição expressa de lei, para satisfazer interesse ou sentimento pessoal".

Podemos resumir a accountability horizontal em democracias consolidadas como o monitoramento contínuo das agências estatais, exercido por outras agências ou mesmo por agentes internos. As agências possuem discricionariedade para exercer suas tarefas. O propósito principal do monitoramento é garantir que as autoridades se sujeitem à lei e atuem da maneira esperada, pelo interesse público. Caso contrário, deverá haver punições para coibir os desvios de conduta.

O monitoramento e a possibilidade de punição são essenciais para a accountability horizontal. Mas como são observadas essas qualidades? Como elas acontecem? Com isso em mente, Taylor e Buranelli (2007) desenharam a accountability horizontal de modo a compreender a atuação das agências nesse sentido.

\subsection{O processo interativo da accountability horizontal}

No artigo Ending up in Pizza: Accountability as a Problem of Institutional Arrangement in Brazil (2007), Taylor e Buranelli estudam instituições de accountability horizontal do âmbito federal, situadas entre o sistema eleitoral e o judiciário. Os autores propõem que "accountability deve ser conceitualizada como um processo dinâmico, ao invés de pensá-la como um estado estático no qual os agentes são passíveis de accountability ou não.” (ibidem, p.62, tradução nossa) Com isso, há uma fuga do conceito nuclear/ radial propostos por Lindberg e Schedler, a fim de compreender a performance da accountability. O processo interativo é dividido em três etapas, cada uma com atores e procedimentos possivelmente distintos e diferentes padrões de atuação e sanção:

1. Supervisão ${ }^{6}$ dos agentes públicos, que possui uma ênfase ex ante, que consiste em localizar falhas na atuação ou prevaricação antes que o problema aumente.

2. Investigação das denúncias contra agentes públicos, geralmente ex post, concentrando-se em tentar descobrir a extensão do delito ocorrido.

3. Sanção, ou a tomada de medidas em resposta a determinados atos de agentes públicos.

O que se deve ressaltar é que para que a accountability política realmente exista, deve haver alguma punição - por mais sutil que seja - para os delitos cometidos pelos agents.

\footnotetext{
${ }^{5}$ Estatal e não-estatal
} 
Comparando o conceito de Taylor e Buranelli com os trabalhos de Lindberg e Schedler, podemos relacionar as etapas um e dois dispostas acima com a característica quatro do conceito núcleo/radial, e com a dimensão de answerability do conceito bidimensional. A característica cinco de Lindberg, a dimensão de enforcement e a terceira etapa de Taylor e Buranelli correspondem à necessidade de algum tipo de punição, para a accountability ser efetiva.

No entanto na argumentação de Taylor e Buranelli, o caráter interativo da accountability fica mais claro. Como um processo, ela envolve múltiplos atores em diversas etapas. O trabalho dos autores investiga a interação de várias agências que combinadas produzem um resultado final (TAYLOR e BURANELLI, 2007, p.63). Como Mainwaring afirma, existe uma "rede de mecanismos de accountability" (apud ibidem, p.63), na qual várias instituições interagem e influenciam no processo geral de accountability, em suas três etapas. O resultado da interação individual das agências não produz necessariamente um impacto positivo no processo geral:

A sobreposição de áreas de responsabilidade, ou, pelo contrário, lacunas entre áreas de responsabilidade, e a extrema independência das diversas instituições podem combinar-se para criar um sistema marcado por notável desempenho institucional em alguns níveis, mas ineficiência geral. (ibidem, p. 63, tradução nossa)

\subsection{A accountability política}

Com as diversas abordagens vistas sobre accountability, podemos inferir algumas características importantes para a avaliação das instituições políticas nesse quesito. Primeiro, a accountability sempre demanda ao menos duas entidades distintas. Como visto nas características um a três, é necessário um agente com certo tipo de poder ou autoridade, e a prática desse poder é passível de ser considerada delituosa, logo a necessidade da accountability. Dentro do próprio Estado, em democracias consolidadas, existem diversas agências responsáveis pelo controle do poder estatal, que possui várias formas. Pela teoria democrática, nenhuma instituição deve ter discricionariedade máxima: "o controle da atividade estatal deve ser visto como um dos eixos que dão sustentação ao regime democrático" (PINHO e SACRAMENTO, 2009, p. 1350). Logo deve haver um controle mútuo, uma "rede de mecanismos de accountability".

Segundo, a accountability só pode existir por causa de dois critérios: a informação e os juízos punitivos. Como visto nas características quatro e cinco de Lindberg, e nas duas dimensões

\footnotetext{
${ }^{6}$ No original: oversight
} 
de Schedler, o acesso à informação é imprescindível para um julgamento do exercício do poder, e a punição por ações delituosas faz-se necessária para coibir futuros atos indevidos.

Terceiro, a accountability é um fenômeno que assume múltiplas formas, devido às diversas intensidades que ela assume. A tipologia dos subtipos de Lindberg deixa bem claro que se pode encontrar "várias accountabilities” em um mesmo recorte de estudo. Estudar a accountability política é extremamente complicado, pois há uma miríade de fenômenos ocorrendo a todo o instante: estudar "microaccountability" é uma tarefa árdua e que consome tempo, enquanto que a “macroaccountability” necessita deixar alguns fatos de lado para levar os estudos adiante.

Como fronteira conceitual utilizada neste trabalho, accountability doravante tem o sentido de mecanismos formais de controle político, "uma relação formal de supervisão e/ou sanções de agentes públicos por outros atores" (MAINWARING, 2003, p. 7) Entretanto, quando especificado, também serão levados em conta os mecanismos informais de accountability, como dispostos na tipologia de Lindberg. 


\section{Accountability no Brasil}

Na América Latina, a noção de accountability encontrou território para germinar com a queda dos regimes autoritários nos anos 80. De fato, o conceito só poderia ser cultivado em um terreno democrático, não fazendo sentido discuti-lo antes da instituição da democracia, como afirmam Pinho e Sacramento: "como pensar em exigir prestação de contas em regimes ditatoriais, nos quais a liberdade de expressão é tolhida e os dirigentes não são delegados 'no' poder, mas usurpadores 'do' poder?” (2009, p. 1350) Conseqüentemente, o termo vem sendo trabalhado no Brasil há relativamente pouco tempo.

Outro motivo para a recente ascensão do conceito no debate político da América Latina, de acordo com Mainwaring, são as preocupações sociais com a corrupção e a insatisfação perante o governo, além de a accountability estar relacionada com a eficiência de políticas públicas. (2003, p.5)

\subsection{A tradução para o português}

Uma das obras pioneiras sobre o tema no Brasil foi o artigo de Anna Maria Campos: Accountability: quando poderemos traduzi-la para o português? (1990) "Tradução" neste caso remete não somente à falta de uma palavra em português semanticamente fiel ao termo em inglês, mas também a um questionamento de Campos sobre a incorporação de valores agregados ao conceito de accountability em território brasileiro.

Apesar do trabalho de Campos ter sido publicado em 1990, ele foi produzido em 1987, antes da introdução da atual Constituição Federal no ano seguinte. O contexto da autora era ainda de transição para a democracia, e o autoritarismo, experiência política vivida. Pela conjuntura política da época (regime militar, burocracia retrógrada, Estado paternalista), pode-se perceber uma grande defasagem institucional para o desenvolvimento de práticas de accountability. 
Para O’Donnell (1998), as recentes democracias da América Latina ainda não apresentam uma estrutura de accountability sólida. Ainda que tenhamos, por definição, os critérios definidos por Dahl (1989) para uma poliarquia (que seria uma democracia sustentável), existem certas fragilidades dos mecanismos de accountability.

$\mathrm{Na}$ dimensão vertical, a qualidade do controle do governo pela sociedade civil ainda gera dúvidas. Não existem certezas sobre sua eficácia em premiar ou punir políticos nas “condições que prevalecem em muitas novas poliarquias (sistemas partidários pouco estruturados, alta volatilidade de eleitores e partidos, temas de política pública pobremente definidos, e reversões políticas súbitas)" (O’DONNELL, p. 29). O fato de eleições ocorrerem apenas de tempos em tempos, aliado a estruturais e complexos problemas de informação, monitoramento e compromisso dificulta ainda mais a accountability eleitoral: “a votação retrospectiva que toma informações apenas no desempenho passado do candidato não é suficiente para induzir os governos a atuarem responsavelmente" (PRZEWORSKI E STOKES apud O’DONNELL, 1998, p. 29). No caso brasileiro, segundo a análise de Campos (1990) a eficácia é ainda menor, pois muitos eleitores vendem seus votos.

As reivindicações sociais e a atuação da mídia também se encaixam como instrumentos de accountability vertical. Quanto ao primeiro, O’Donnell (1998) coloca que em última instância é o governo quem decide como irá atuar em relação às demandas sociais. A falta de resposta a exigências populares cria um clima de descontentamento. A mídia se situa como um intermediário entre as ações do governo e o público, moldando a opinião pública com as informações divulgadas na imprensa escrita e televisual. A responsabilidade por informar o público sobre a atuação do Estado gera um grande poder, e na falta de medidas estatais adequadas, a mídia tende a substituir os tribunais. Ela pode "poupar corruptos e condenar inocentes" pela moldagem da opinião pública. Tal prática ocorre no Brasil - ao menos na época do artigo de Campos - por termos uma mídia que não exerce adequadamente seu papel de vigilante, sendo "subserviente a interesses e conveniências particulares" (CAMPOS, 1990, p.9).

Na dimensão horizontal, a análise de Campos - do cenário do fim dos anos 80 apontava para uma supremacia do Executivo sobre os outros poderes, em grande parte devido a décadas de autoritarismo. No Poder Legislativo, os representantes "parecem só preocupados com seus interesses pessoais e as conveniências de seus parentes e amigos” (ibidem, p.10). Décadas de 
ditadura parecem ter prejudicado a força da representatividade. O Poder Judiciário seria dependente do Executivo, inclusive quanto aos recursos financeiros. Com uma sociedade civil pouco organizada, um processo informacional defeituoso entre o Executivo e os demais Poderes (e entre o Estado e a população) e a debilidade das instituições democráticas, não havia espaço para o desenvolvimento de agências de accountability horizontal.

\subsection{O caminho para a tradução}

Segundo Campos, as características institucionais brasileiras do fim da década de 80 não eram adequadas para uma administração pública transparente e compatível com as expectativas políticas. A estudiosa formula alguns requisitos para o desenvolvimento da accountability política: a) organização da sociedade civil, para fazer valer a noção dos cidadãos como fonte do poder político; b) descentralização do aparato governamental, diluindo a concentração de poder nas mãos de alguns e possibilitando a atuação de agências de accountability horizontal; c) emergência de novos valores sociais, no lugar dos tradicionais. (1990, p.18)

Tendo como ponto de partida o trabalho de Campos, Pinho e Sacramento (2009) realizam um estudo intitulado: Accountability: já podemos traduzi-la para o português? O nome é uma referência ao artigo da estudiosa, e os autores buscaram avaliar possíveis mudanças no contexto brasileiro, rumo à accountability. Vinte anos após a análise de Campos, o cenário político apresenta um perfil diferente daquele de 87: nova Constituição Federal, paradigma da Nova Gestão Pública, reformas neoliberais e globalização.

A mera reconfiguração das instituições formais - visando ampliar mecanismos de controle político - não é suficiente para a ascensão de uma cultura de accountability na América Latina. A emergência de novos valores sociais é vista por vários estudiosos, como apontam Pinho e Sacramento (2009), como necessária para combater antigas práticas associadas com as tradições oligárquicas da história da América Latina. Certos neoconservadores americanos - como S. Huntington e F. Fukuyama - atentam para um elemento subjetivo (o caráter) necessário ao desenvolvimento político.

Logo para o Brasil faz-se necessário um desenvolvimento de uma nova cultura política. Krushnir e Carneiro a definem como "o conjunto de atitudes, crenças e sentimentos que dão origem e significado a um processo político, evidenciando as regras e pressupostos que orientam o 
comportamento de seus atores.” (apud ibidem, p. 1360) Essa nova cultura deve superar as práticas históricas, como o clientelismo, paternalismo, patrimonialismo e personalismo. Tais práticas vão de encontro a princípios básicos da teoria democrática, como a primazia das demandas coletivas sobre as individuais no processo político decisório.

O confronto dos princípios democráticos com os traços tradicionais brasileiros leva O’Donnell (1994) a caracterizar nossa democracia como “delegativa”. É um tipo de democracia na qual os vitoriosos possuem discricionariedade para agir da maneira que interessá-los, não sendo prioritário o cumprimento das propostas de campanha. O cientista político Renato Lessa (FOLHA DE SÃO PAULO, 2011) sugere que o presidencialismo de coalizão brasileiro exibe uma "lógica mafiosa". Essa lógica sugere que delitos do governo somente são expostos quando há algum atrito na oligarquia política, e a correção é feita mediante trade-offs dentro da própria oligarquia. Neste sentido, podemos falar de accountability política interna às elites políticas, na qual a sociedade fica em segundo plano. Um dos motivos para isso é a fraca accountability eleitoral, pois os eleitores não punem apropriadamente os delitos de grupos políticos.

Quanto à organização da sociedade civil - compreendida como a maneira da sociedade se organizar politicamente para influenciar a ação do Estado - Evelina Dagnino considera a década de 80 como um período de ressurgimento, um marco da "fundação efetiva da sociedade civil no Brasil” (apud PINHO e SACRAMENTO, 2009, p.1355). As lutas contra o regime ditatorial nessa época teriam impulsionado, segundo a autora, o associativismo e a emergência de movimentos sociais organizados. Outros autores, como Avritzer, também visualizam os anos 80 como um período em que "novos potenciais culturais de construção democrática emergiram e novas práticas, movimentos e instituições tornaram-se possíveis" (apud ibidem, p. 1355).

Outro ponto de destaque são as lutas pelas eleições diretas em 1984. Se as primeiras eleições diretas para a presidência pós-redemocratização levaram à escolha de Fernando Collor "um presidente despreparado, autoritário e messiânico" (CARVALHO, apud PINHO e SACRAMENTO, 2009, p. 1356), o movimento posterior que resultou em seu impedimento foi importante como demonstração de iniciativa cidadã. Carvalho considera tal movimento "uma vitória cívica importante, pois deu aos cidadãos a sensação inédita de que podiam exercer algum controle sobre os governantes" (CARVALHO apud ibidem, p.1356). 
Sorj e Santos (apud ibidem, p.1356) expõem as mudanças nas características das organizações sociais, com a transição para a democracia liberal. Grupos que antes influenciavam o debate público como um todo se voltaram aos interesses particulares e corporativos, visando atender demandas sectárias. Na ausência de uma crítica normativa à estrutura política, restaram demandas individualizadas de diversos grupos com interesses distintos.

Apesar da reconfiguração dos antigos grupos para se inserir nos novos sentidos sociais, Pinho e Sacramento (2009) ressaltam o surgimento de novas organizações, como Instituto Ethos e o Movimento de Combate à Corrupção Eleitoral (MCCE). O escopo dessas organizações está diretamente relacionado à instituição de práticas relacionadas à accountability. O MCCE foi o responsável pelo primeiro projeto de iniciativa popular convertido em lei: a Lei $\mathrm{n}^{\circ}$ 9.840/99, conhecida como Lei de Combate aos Crimes Eleitorais. O Movimento também foi decisivo para a implantação da Lei da Ficha Limpa, e atualmente é um dos bastiões do movimento por uma reforma política.

Campos (1990) em sua análise considera nociva a supremacia do Executivo Federal no processo político. De fato para a accountability ser efetiva é necessário uma difusão do poder a fim de, por exemplo, viabilizar a atuação das agências de accountability horizontal. Pinho e Sacramento observam que a nova Constituição definiu os municípios como entes da federação, e a partir dos anos 90 várias leis e políticas foram transferindo atribuições da esfera federal e estadual para os governos municipais: "cada vez mais os governos locais assumem maior autonomia e responsabilidades na gestão e execução de políticas públicas” (2009, p. 1358-1359). Uma vez que em certo sentido o cidadão habita uma cidade, mas não um estado ou uma federação, a transferência de competências para a esfera municipal possibilita um maior contato com as instâncias decisórias e o processo político, aprofundando a democracia e a visibilidade do representante.

Nos últimos vinte anos, um grande número de medidas contribuiu para a descentralização e para fortalecer os mecanismos de controle da sociedade civil: a instituição do Orçamento Participativo; a implantação da Lei de Responsabilidade Fiscal; a criação da Controladoria Geral da União; o Sistema de Administração Financeira do Governo Federal (Siafi); as TVs e rádios da Câmara e do Senado Federal; entre outras. (ibidem, p. 1358-59) Até o Judiciário, um ramo tradicionalmente resiliente na América Latina, foi passível de reformas: a Emenda 
Constitucional $\mathrm{N}^{\circ} 45$ de 31 de dezembro de 2004 instituiu o Conselho Nacional de Justiça (CNJ) e também o Conselho Nacional do Ministério Público (CNMP).

\subsection{Accountability no Judiciário brasileiro}

Quando se estuda a accountability política de um país, o ramo Judiciário é de extrema importância. Na maioria dos casos a punição por ações delituosas - característica cinco de Lindberg - é de estabelecida pelos tribunais. Como é considerado por O'Donnell: "a efetividade da accountability horizontal depende não apenas de agências isoladas lidando com questões específicas mas com uma rede dessas agências que inclui tribunais comprometidos com o apoio a esse tipo de accountability." (1998, p. 46) Portanto a atuação do Judiciário como agência de accountability horizontal é vital para evitar que todo o sistema opere imperfeitamente.

Uma das sugestões de O’Donnell para a ascensão da accountability horizontal é justamente a existência de cortes independentes do Executivo e Legislativo, com orçamento próprio e servidores profissionalizados. No entanto o próprio autor expõe os riscos dessa autonomia, afirmando que ela (ibidem, p.49)

pode facilitar o controle do Judiciário por um partido político ou uma facção ou coalizão de interesses duvidosos, ou pode promover uma auto-definição privilegiada e arcaica da corporação judicial e de sua missão, sem qualquer accountability própria em relação a outros poderes do Estado e da sociedade

O Brasil é inclusive citado por O'Donnell como um exemplo da extra-limitação da autonomia do Judiciário. O país teria concedido ao Judiciário forte autonomia em relação ao Executivo e ao Congresso (que trouxeram melhorias significativas no desempenho judicial). Com a autonomia garantida, o Judiciário a utilizou para atribuir altos salários para juízes e outros funcionários, além de "privilégios imensos", especialmente nos Tribunais Superiores e em outros Tribunais (TST, STJ, STM, TSE, TJs, etc.).

Na teoria democrática, uma série de estudiosos como Domingo (1999), O’Donnell (1998) e Rodrigues (2008) levanta questionamentos sobre a Independência do Judiciário. A autonomia política pode ser crucial, no entanto (DOMINGO apud RODRIGUES, 2008, p. 35):

Da mesma forma que o Judiciário de maneira ideal [atua] como fiscal dos outros poderes do Governo, é desejável também que os juízes sejam sujeitados a algum grau de controle político para garantir um nível de accountability democrática 
dentro do Poder Judiciário. Isso é ainda mais importante quando as decisões judiciais têm um impacto político, uma vez que através de suas decisões os juízes também participam do processo de criação das leis e função social de controle do Estado. Desse modo, o objetivo do princípio da separação dos poderes é alcançar um grau ideal, e não máximo, de independência institucional.

Desta forma, existem dois problemas principais quanto à accountability política do Judiciário. O primeiro diz respeito à atuação do Judiciário como agente de accountability horizontal, responsável principalmente pela punição de delitos cometidos por oficiais públicos. O segundo remete à accountability interna do Judiciário, pois este também deve ser submetido a controle, monitoramento e regulação.

Rodrigues (2008) coloca que o Judiciário brasileiro com a nova Constituição ganhou novos traços, tendo maior independência em relação ao Executivo e mais vias de acesso aos recursos jurídicos pela população. Apesar das reformas, muitos brasileiros ainda vêem os tribunais como recurso inoperante, jurássico e disfuncional, incapaz de auxiliar a sociedade civil a influenciar a política (TAYLOR apud ibidem, p. 48). Por outro lado, o Judiciário a partir dos anos 90, com sua autonomia em relação ao Executivo, conseguiu manifestar força política ao bloquear reformas pela via do Controle Constitucional (reforma do Inss abandonada, taxas declaradas inconstitucionais, etc. - o fenômeno chamado por alguns de "judicialização da política") Apesar da ampliação do acesso, afirma Rodrigues, os maiores "clientes" dos tribunais superiores continuam sendo grupos políticos restritos.

Pilar Domingo (1999) dispõe os mecanismos institucionais que visam garantir a independência do judiciário. Primeiro, há a forma de ingresso na carreira: a forma de recrutar os magistrados brasileiros é via concurso público, o que garante autonomia dos novatos perante a instituição, sem "dever favores". Segundo, o sistema de estabilidade ${ }^{7}$ busca garantir mais liberdade perante a instituição: no Brasil, os juízes possuem "garantia de vitaliciedade, irredutibilidade de vencimentos, inamovibilidade e garantia de perda do cargo apenas por decisão colegiada de seus pares de instância imediatamente superior" (RODRIGUES, 2008, p.49). O último ponto colocado por Domingo é a necessidade de autonomia financeira e salários decentes. Ambos estão presentes no Brasil: os tribunais possuem autonomia administrativa e financeira, e os servidores do Judiciário estão dentre os mais bem remunerados da carreira pública.

\footnotetext{
${ }^{7}$ No original, tenure system.
} 
As disposições institucionais brasileiras atuais garantem um alto grau de independência ao Judiciário. Com isso ele consegue exercer sua função de controle constitucional sem grandes barreiras. Porém (SANTISO apud ibidem, p. 50),

a questão principal no Brasil não é se o Judiciário é suficientemente independente, mas se se tornou excessivamente independente. [...] No Brasil o desafio reside no fortalecimento da accountability do judiciário perante a sociedade e a política [...] Alegações de desperdício de dinheiro, nepotismo e corrupção são comuns, refletindo em negligência burocrática com a accountability financeira. Em 1994, por exemplo, a Justiça Federal tinha um orçamento de aproximadamente um milhão e meio de dólares, mas gastou 880 milhões acima do orçamento sem qualquer receio de punição. [...] $\mathrm{O}$ abuso institucional da autonomia funcional também ocorre com os abusos individuais feitos por juízes, que abusam de seus privilégios.

No novo regime democrático brasileiro, o problema do "excesso de independência" do Judiciário floresceu no debate político. Desde a Assembléia Constituinte, a idéia de um Conselho de Justiça é discutida. A razão para a criação de um Conselho seria a racionalização da administração da justiça e a manutenção da independência do Judiciário. No entanto, afirma Santiso, a meta prioritária seria a ampliação da accountability interna do Judiciário e mais transparência perante a sociedade.

Com o decorrer dos debates e formação de consensos sobre a criação de um Conselho de Justiça - por uma reforma do Judiciário - em 2004 a Emenda Constitucional № 45 é promulgada pelo Congresso Nacional. No ano seguinte, o CNJ e o CNMP são instalados. Apesar de o Ministério Público não fazer parte do Judiciário, sua estrutura é semelhante. Possivelmente a criação do CNMP refletiu demandas por maior transparência e accountability no Ministério Público, assim como aconteceu com o CNJ. 


\section{O Ministério Público}

O promotor de justiça Maurício Augusto Gomes (1989), ao traçar um panorama da evolução constitucional do Ministério Público, denota que este como instituição formal origina-se com a Constituição de 1934. Anteriormente, as Constituições de 1824 e 1891 faziam menção apenas ao Procurador da Coroa e ao Procurador Geral da República, respectivamente. Interessante notar que na Constituição imperial a menção estava contida no Capítulo III ("Do Senado") do Título IV ("Do Poder Legislativo") enquanto que no texto da República Velha, na Seção III ("Do Poder Judiciário”). José Frederico Marques considera como gênese do Ministério Público no Brasil as "Ordenações Manuelinas de 1514 e seus aperfeiçoamentos trazidos pelas ordenações posteriores" (apud ibidem, p.64).

A Constituição de 1934 foi a primeira a destacar o Ministério Público dos três poderes tradicionais, dispondo-o em uma seção própria (I) de um Capítulo à parte, denominado "Dos órgãos de Cooperação nas Atividades Governamentais". O Procurador Geral da República, assim como acontece atualmente, era nomeado pelo Presidente da República, dependendo de aprovação pelo Senado. Entretanto, a demissão ad nutum - à discrição da autoridade - estava possibilitada (artigo 95, parágrafo $1^{\circ}$ ). Atualmente, para a saída compulsória do cargo, é necessária a aprovação por uma maioria absoluta dos integrantes do Senado.

O texto de 1934 também indicou o ingresso na carreira, no âmbito federal, se faria mediante concurso. Este processo de admissão também estaria indicado nas Constituições mais “democráticas” posteriores (as de 1946, 1967 e 1988). A perda do cargo só aconteceria mediante sentença judiciária ou processo administrativo com direito a ampla defesa (parágrafo $3^{\circ}$ ).

Tal evolução nas garantias dos servidores do Ministério Público, junto à crescente autonomia da instituição, se daria com avanços e retrocessos nas seguintes Constituições. Como afirma Maurício Gomes (ibidem, p.65-68), em tempos sombrios de democracia o Ministério Público vai sendo minimizado, e sua autonomia enfraquecida. Nas Constituições de 1937 e 1969, há pouquíssimas referências à instituição, e as que existem estão inseridas respectivamente sob a seção 
que trata do Poder Judiciário (assim como no texto de 1967), e sob o capítulo que trata do Poder Executivo. No entanto, pode-se visualizar uma tendência constitucional de concessão de autonomia senão à instituição, ao menos aos servidores: desde 1946, certas garantias, como ingresso mediante concurso, estabilidade após dois anos de exercício e inamovibilidade estão presentes. A aproximação com a magistratura também procede: a Carta de 1967 equipara os vencimentos e aposentadorias dos membros do Ministério Público aos daqueles.

Ao avaliar o histórico constitucional brasileiro, certamente a Constituição de 88 é a que mais concede garantias e autonomia ao Ministério Público. De acordo com as expectativas com relação a um Estado Democrático de Direito (artigo $1^{\circ}$ da $\mathrm{CF}$ ), as atribuições conferidas ao Ministério Pública na Carta "afastam definitivamente a instituição da defesa dos interesses do Estado, posicionando-a como a instituição de defesa em Juízo, especialmente mas não apenas, dos interesses dos interesses da sociedade, até mesmo contra o Estado.” (ibidem, p.68) Ou como coloca Arantes, a autonomia do Ministério Público e independência funcional desloca-o "da tarefa de defender o Estado para a condição de fiscal e guardião dos direitos da sociedade” (1999, p.84)

Em nossa atual Constituição, o Ministério Público está disposto no Título IV ("Da Organização dos Poderes"), Capítulo IV ("Das Funções Essenciais à Justiça"), em uma seção própria (Seção I, “Do Ministério Público”). Interessante notar que como a instituição está inserida em um capítulo distinto dos três tradicionais poderes, isso abre margem para considerar o Ministério Público um “quarto poder”.

No artigo 127, dispõe-se que “O Ministério Público é instituição permanente, essencial à função jurisdicional do Estado, incumbindo-lhe a defesa da ordem jurídica, do regime democrático e dos interesses sociais e individuais indisponíveis.” O parágrafo $1^{\circ}$ do artigo 127 indica os princípios institucionais do Ministério Público: unidade, indivisibilidade e independência funcional.

Para o promotor Gomes, o princípio da unidade significa que a atuação dos membros do Ministério Público deve ser reflexo das intenções da "Instituição" (1989, p.69):

todos os membros de determinado Ministério Público fazem parte de único órgão sob a direção de único chefe, sendo que a divisão do Ministério Público em diversos organismos ocorre apenas por causa de racional divisão do trabalho, mas 
todos eles atuam pelos mesmos fundamentos e com as mesmas finalidades, constituindo-se pois, numa única Instituição

Como princípio da indivisibilidade, o promotor entende que todos os membros do Ministério Público são "representantes" equivalentes da Instituição: se em um processo o Promotor ou Procurador de Justiça deve ser substituído, não há quaisquer alterações processuais. O Ministério Público é o mesmo, e os promotores, membros equivalentes.

Por princípio da independência funcional, Gomes entende que

o membro do Ministério Público no exercício de suas funções atua de modo independente, sem qualquer vínculo de subordinação hierárquica inclusive com relação à chefia da instituição, guiando sua conduta somente pela lei e por sua convicção. Assim, somente no plano administrativo se pode reconhecer subordinação hierárquica do membro do Ministério Público com relação à chefia ou órgãos de direção superior da instituição, jamais no plano funcional, onde seus atos somente estarão submetidos à apreciação judicial, nos casos de abuso de poder que possam lesar direitos.

Os três princípios representam grandes abstrações que geram problemas ao tentar relacioná-los no empírico. Os dois primeiros sugerem que todos os membros atuam de forma igual, e suas motivações e convicções internas não fazem diferença no exercício funcional. É claro que a própria definição de princípio implica uma idealização, que é dificilmente atingida na prática. Tais princípios podem até levar a problemas na eficiência institucional, por exemplo: ao se considerar que a substituição de um procurador ou promotor por outro em certo processo não infere em alterações processuais, não se leva em conta que o substituto inicialmente tem menos informações sobre o processo, que no quesito celeridade seria melhor manter sempre uma pessoa responsável pelo caso.

O terceiro princípio inclusive é contraditório com os demais. Se os membros do Ministério Público não devem subordinação hierárquica a seus superiores, guiando-se "pela lei e por sua convicção", isso implica que há possibilidade de conflitos de interesse entre chefia e demais membros. Se há tal possibilidade, então há mesmo unidade institucional? Há mesmo um Ministério Público indivisível, com interesses e atuações unívocas? Considerando a existência de unidade e indivisibilidade, deveria haver um critério firme para julgar a legitimidade da atuação dos membros. E nesse caso, quem seria o principal? Deveria ser os superiores? Membros de outros poderes? O princípio da independência funcional obscurece a resposta para esta pergunta. A definição de "ações 
delituosas", que a accountability serve para coibir, fica mais complicada quando a atuação dos procuradores e promotores é guiada "somente pela lei e suas convicções", e não há indivíduos ou grupos externos apresentando e utilizando um critério conciso de atuação.

É claro que uma Constituição não é lida para entender como as coisas são, e sim como elas devem ser. No entanto o impacto empírico de suas prescrições é importante e deve ser analisado.

Também podemos nos perguntar se a estruturação funcional da instituição segue o critério democrático-liberal esperado: como questiona Santiso (apud RODRIGUES, 2008, p. 50) a respeito do Judiciário, o Ministério Público brasileiro talvez tenha se tornado demasiado independente.

Além da garantia de independência funcional, o Ministério Público também possui outras características que o colocam em simetria com a organização do Poder Judiciário: ambos se organizam em duas partes, uma do âmbito da União e outra dos Estados. O Ministério Público da União inclui o Federal, o do Trabalho, o Militar e o do Distrito Federal e Territórios. Esta simetria Gomes chama de "lógica e racional, pois é perante o Judiciário que o Ministério Público atua preponderantemente.” (1989, p. 70)

Como também acontece com o Poder Judiciário, ao Ministério Público foi concedida autonomia funcional, administrativa e financeira. Cabe-lhe a tarefa de elaborar "sua proposta orçamentária dentro dos limites estabelecidos na lei de diretrizes orçamentárias" (Art. 127, parágrafo $3^{\circ}, \mathrm{CF}$ ). Também é poder do Ministério Público "propor ao Poder Legislativo a criação e extinção de seus cargos e serviços auxiliares, provendo-os por concurso público de provas ou de provas e títulos, a política remuneratória e os planos de carreira", conforme o parágrafo $2^{\circ}$ do mesmo artigo. Com tantas semelhanças com o Poder Judiciário, questionamentos como aqueles dispostos por Rodrigues (2008) quanto à accountability, possivelmente também são pertinentes ao Ministério Público.

Os procuradores e promotores de justiça do Ministério Público, como os magistrados, também possuem uma série de garantias que buscam efetivar a independência funcional dos integrantes da instituição. O ingresso na carreira é mediante concurso público, baseado no mérito; após dois anos de exercício do cargo, a perda deste só ocorre por decisão judicial transitada em 
julgado; o afastamento das funções só ocorre por interesse público, por votos de maioria absoluta dos membros de órgão colegiado do Ministério Público, com direito a ampla defesa (antes da Emenda Constitucional $\mathrm{n}^{\circ} 45 / 2004$, era necessário dois terços dos votos); e os rendimentos também estão assegurados, com garantia de irredutibilidade.

\subsection{A importância do Ministério Público}

A Constituição de 1988 promoveu o Ministério Público a defensor do cidadão, atribuindo-lhe novas competências de acordo com novos direitos - os difusos e coletivos - que representaram "uma nova categoria dentro do ordenamento jurídico tradicional, de matriz liberal e princípios de organização essencialmente individualistas" (ARANTES, 1999, p.84). Sobre o novo semblante institucional, Kerche entende que (2007, p.260)

o leque de atribuições do Ministério Público é extenso, permitindo afirmar que há poucos assuntos referentes à sociedade brasileira que não possam ser transformados pela instituição em uma questão judicial. De um crime passional ao desvio de dinheiro por parte de um burocrata, passando pela poluição de um rio ou pelo direito de um político se candidatar em uma eleição, quase todos os assuntos podem ser judicializados pela instituição.

Gomes destaca sete funções institucionais do Ministério Público previstas na Constituição: 1) Ação penal pública; 2) Defensor do povo (“Ombudsman”); 3) Defesa dos interesses difusos; 4) Ação de inconstitucionalidade; 5) Ação interventiva; 6) Defesa dos interesses indígenas; 7) Controle da atividade policial (1989, p. 73-75)

Como responsável pela ação penal pública, o Ministério Público torna-se praticamente o único responsável pelo processo penal de indivíduos (a exceção acontece quando o Ministério Público não cumpre sua função, não oferecendo a denúncia no prazo legal). A possibilidade de ação penal por autoridade policial ou autoridade judiciária, oriunda da Lei nº4.611 de 1965, tornou-se extinta. Portanto o Ministério Público é uma importante agência de accountability horizontal, atuando como principal. O papel de instaurador de processos penais é fundamental, uma vez que sanções desse tipo são mais temíveis que sanções administrativas.

O Ministério Público também cumpre papel de defensor do cidadão e da sociedade, pois lhe foi atribuída a tarefa de "zelar pelo efetivo respeito dos Poderes Públicos e dos serviços de relevância pública aos direitos assegurados nesta Constituição, promovendo as medidas necessárias 
a sua garantia" (art.129, inciso II, CF) e "promover o inquérito civil e a ação civil pública, para a proteção do patrimônio público e social, do meio ambiente e de outros interesses difusos e coletivos" (art.129, inciso III, CF). Gomes compreende que "interesses coletivos são aqueles que atingem um grupo determinado ou determinável de pessoas, enquanto os interesses difusos são aqueles que atingem um grupo indeterminável de pessoas” (1989, p. 74). Vale ressaltar que na esfera jurídica brasileira, esse papel do Ministério Público é recente - a primeira lei que disciplina a ação civil pública de responsabilidade é datada de 1985 (ademais, o inquérito civil foi criado por esta lei).

A expansão da alçada do Ministério Público para o campo dos direitos difusos e coletivos faz parte, segundo Arantes, de um processo de "judicialização de conflitos políticos" e "politização do sistema judicial", uma vez que "tais direitos têm geralmente conotação política" (1999, p. 83). Como agente político, o Ministério Público também atua no controle constitucional: é legítima ao órgão a ação direta de inconstitucionalidade de lei ou ato normativo estadual ou municipal, quando expresso na Constituição do Estado em questão , e é poder do Procurador Geral da República acionar o Supremo Tribunal Federal para uma ação direta de inconstitucionalidade de lei ou ato normativo federal, municipal ou estadual (poder que lhe era exclusivo até a Constituição de 1988).

O Ministério Público na democracia brasileira é bastante importante para o sistema de pesos e contrapesos, e para o trabalho judicial. Medidas foram implementadas para que lhe fosse garantida a atuação independente frente aos três poderes tradicionais. Com esta independência e a elevada discricionariedade, faz sentido caracterizar o Ministério Público como quarto poder. Portanto, tratar o Ministério Público como agência de accountability horizontal, segundo os critérios de O’Donnell (1998), é relevante para o estudo da democracia brasileira.

\subsection{O Ministério Público como agência de accountability (principal)}

Como instituição de controle, instauradora de processos penais, investigativa e interventiva, o Ministério Público cumpre papel essencial para a pluralidade democrática. As características dispostas por O’Donnell (ibidem, p.40) estão significativamente presentes no corpo jurídico constitucional que fundamenta a atuação da instituição. O direito e poder legal para atuação, como visto acima, estão juridicamente garantidos, e igualmente a capacidade para realizar 
ações (garantida pela autonomia do órgão). A disposição para atuar é mais difícil de ser analisada e exige um trabalho extenso. A análise da relação entre capacidade e disposição é complexa (pode-se argumentar, por exemplo, que há muita disposição e pouca capacidade, ou pouca disposição e muita capacidade, etc.).

Fábio Kerche, em seu artigo Autonomia e Discricionariedade do Ministério Público no Brasil (2007), denota que o Ministério Público brasileiro possui características peculiares para uma instituição de grande magnitude na estrutura democrática. Possui grande autonomia (como será visto abaixo), mas também um grande leque de atribuições e poder de ação. Kerche indica que geralmente uma alta autonomia é dada para órgãos com uma alçada pouco ampla, uma vez que (ibidem, p. 271):

quanto maior o leque de atribuições e mais vaga a legislação - aumentando a chance de discricionariedade dos atores não-eleitos -, maior deve ser 0 accountability para que o principal possa acompanhar o desempenho de seu agent (...), quando se limita o grau de discricionariedade, as chances de arbitrariedades também diminuem, tornando mais razoável em uma democracia a existência de órgãos com altas doses de autonomia.

O estudioso em seu trabalho analisa três grandes funções do Ministério Público: promoção da ação penal pública, físcalização de políticos e defesa do cidadão e da sociedade.

Quanto à ação penal pública, o princípio da legalidade obriga os promotores a levar todos os casos ao Poder Judiciário. Neste caso, há baixa discricionariedade, pois procuradores e promotores não possuem liberdade para decidir se irão levar ou não uma ação penal ao Poder Judiciário.

Como agência de accountability horizontal, o Ministério Público se encaixa melhor pelas outras duas funções analisadas por Kerche. E justamente nessas funções, a instituição possui grande discricionariedade.

A atribuição de fiscalizador de políticos vem de um entendimento de que o sistema clássico de controle do poder do Estado - o sistema de pesos e contrapesos - não seria suficiente para garantir a accountability e o império da lei. Desta forma, surgem "órgãos especializados e auxiliares dos poderes de Estado, não previstos na teoria clássica da democracia liberal, para limitar abusos de atores estatais - como as ouvidorias dos países latinos ou os ombudsmen dos países 
nórdicos, por exemplo.” (ibidem, p.273) A peculiaridade do caso brasileiro é que o Ministério Público não atua unicamente em virtude de tal função e seus integrantes possuem grande independência funcional.

Outro aspecto interessante é que o Ministério Público não fiscaliza somente no sentido de levantar informações sobre políticos e fornecê-las para os cidadãos e demais poderes do Estado, como faz o ombudsman. Ele também "detém a capacidade, praticamente, sem a necessidade de consultar outro ator, de levar os políticos ao banco dos réus.” (ibidem, p.273)

Tal poder fiscalizador faz levantar questionamentos quanto à atuação da instituição. $\mathrm{O}$ mesmo que O’Donnell indica sobre a mídia (1998, p.30) pode acontecer nas suas conduções: inocentes podem ser punidos e corruptos poupados, "principalmente com o grau de discricionariedade do Ministério Público em relação à ação civil.” (KERCHE, 2007, p.273). Outro problema é como saber se ele está levando os casos certos para o Judiciário, e se não está deixando alguns de lado. Segundo Arantes, 38\% dos 645 municípios do Estado de São Paulo tiveram seus prefeitos processados até o ano 2000 (apud KERCHE, p.274). Kerche questiona o significado desses números e se não há mais prefeitos que poderiam ter sido processados e não foram. Quando se deixa de processar um prefeito, "pode-se concluir que o Ministério Público deu um certificado de idoneidade ao político, ou que há uma seleção de casos mais importantes que o dele, ou que o promotor é um tipo mais ‘burocrático’ e não deseja confusão em sua comarca.” (ibidem, p.274)

De forma muito interessante, os levantamentos sobre a mídia de O’Donnell se relacionam novamente com um problema apresentado por Kerche. Este dispõe que para alguns promotores tornou-se espécie de estratégia divulgar investigações de políticos à mídia, possibilitando a punição pela opinião pública, mais simples que as complexas condenações por corrupção no Judiciário. Essa prática acarreta todas as críticas feitas por O’Donnell sobre a atuação da mídia como principal de accountability, principalmente quando autoridades oficiais não cumprem corretamente o papel de defesa da lei.

A ação civil pública e o inquérito civil - embora atribuições relativamente recentes são de grande relevância na atuação do Ministério Público. São instrumentos utilizados para fiscalizar o cumprimento correto da lei, incluindo leis constitucionais. 
Apesar de uma miríade de outras instituições estarem legitimadas a recorrer à ação civil pública - como União, estados, municípios, autarquias e empresas públicas - o Ministério Público responde por $90 \%$ das ações, de acordo com Ada Pelegrine Grinover (SADEK apud KERCHE, 2007, p.275). O Ministério Público é portanto o principal ator no uso desse instrumento, "que permite judicializar uma gama imensa de assuntos e que garante a discricionariedade aos integrantes da instituição.” (ibidem, p.275)

Já o inquérito civil é competência exclusiva do Ministério Público, sendo um instrumento utilizado pelos promotores na fase preliminar ao processo judicial para conduzir e coordenar investigações. Os promotores podem então decidir se certo caso deve ou não se transformar em ação civil pública, independentemente de outro ator estatal. A conclusão de Kerche é que (ibidem, p. 275):

mesmo não detendo o monopólio sobre a ação civil pública, o Ministério Público é reconhecidamente o mais importante ator a utilizá-la e mantém um alto grau de discricionariedade sobre este ponto. Portanto, um dos elementos que formalmente serviam de defesa contra a falta de instrumentos de accountability (a obrigatoriedade de levar o caso à Justiça como na ação penal e, conseqüentemente, a pouca discricionariedade) perde sua força, garantindo a um órgão com integrantes não-eleitos, muito pouco accountable, o papel de decidir ou não sobre a procedência de um caso.

Fazendo uso da conceitualização de Taylor e Buranelli (2007), percebe-se que as três etapas do processo de accountability estão presentes como capacidades e atribuições funcionais do Ministério Público. No trabalho dos autores, são estudadas quatro instituições de accountability horizontal localizadas entre a esfera eleitoral e a judicial: o Ministério Público Federal, a Polícia Federal, o Tribunal de Contas da União e as Comissões Parlamentares de Inquérito. A intenção era analisar o resultado final da accountability envolvendo tais instituições, em casos de corrupção de repercussão nacional.

O Ministério Público Federal, segundo os autores, tipicamente não participa durante a etapa de supervisão (2007, p.64). Sua atuação começa quando os delitos foram já percebidos, e pode-se então iniciar investigações. Entretanto, a idéia de grande discricionariedade da instituição, sugerida por Kerche (2007), questiona se não há certa supervisão. Não seriam o inquérito civil e a ação civil pública elementos de supervisão, ao menos em parte? Afinal, um Ministério Público 
atuante não poderia coibir ações delituosas de certos agentes, com seu "amplo leque de atribuições e instrumentos de ação"?

A idéia de supervisão cai bem à função de defensor discricionário de direitos: o Ministério Público está legitimado a supervisionar os exercícios das leis e "a possibilidade de judicializar praticamente qualquer assunto que envolva um grupo de cidadãos" (KERCHE, 2007, p. 277) é um relevante fator de accountability ex ante.

Entretanto, no escopo da pesquisa de Taylor e Buranelli, o Ministério Público Federal possui um papel de supervisão minimizado. A supervisão dos agentes estatais está mais concentrada no Tribunal de Contas da União, sendo o Ministério Público para isso "fracamente equipado" (2007, p.65, tradução nossa).

Como agente de investigação, o Ministério Público é de grande importância. Por ser ele quem decide se haverá ou não processo, ele deve juntar todas as informações pertinentes para analisar os casos. Os inquéritos policiais e os trabalhos das Comissões Parlamentares de Inquérito vão parar em última instância nas mãos dos promotores. No entanto estes não dependem daqueles: "ao ser informado sobre atos contra o interesse público, o Ministério Público Federal freqüentemente começa sua própria investigação para preparar o processo.” (2007, p.64, tradução nossa)

Por ser o agente que aciona o Judiciário, por via da ação penal pública e da ação civil pública, o Ministério Público cumpre uma tarefa essencial ao processo de sanção. Para que haja sanções penais por qualquer delito cometido por oficiais públicos é imprescindível um processo formalizado por um promotor. Logo, no âmbito da investigação e da sanção o Ministério Público é importantíssimo.

No entanto, sua atuação não carece de questionamentos. Taylor e Buranelli indicam alguns problemas que limitam a efetividade do Ministério Público (Federal) como instituição de accountability horizontal: (2007, p.64, tradução nossa)

Não apenas foi o Ministério Público Federal criticado pelo seu ativismo excessivo, devido às buscas de seus membros por atenção da mídia, e pela natureza política de alguma de suas investigações, mas ele tem problemas sérios com a continuidade de seus trabalhos. O volume imenso de casos em potencial, o processo judicial moroso 
e a discrição de promotores para escolher quais casos conduzir acabaram levando o Ministério Público Federal a tender carecer de direção geral.

Outro problema diz respeito à estruturação da informação. Nos casos analisados por Taylor e Buranelli, não houve uma interação eficaz entre o Ministério Público Federal e outras instituições. A falta de um elo permanente, visando ao acúmulo organizado de informações e à cooperação no processo investigativo, prejudica o desempenho das instituições que buscam agir em prol da accountability. Inclusive houve disputas entre o Ministério Público e a Polícia Federal pelo monopólio do poder de investigação (ibidem, p.65).

$\mathrm{Na}$ parte da ação penal também há problemas. Apesar de o princípio da legalidade obrigar os promotores a levar todos os casos ao Poder Judiciário, há poucos estímulos para se buscar conduzir processos. A duração de vários casos pode chegar de cinco até dez anos. Para os membros do Ministério Público, é inclusive mais notável para suas carreiras a etapa das conduções investigativas do que da finalização de processos. "Isso é verdade especialmente porque o sistema judicial, com todo seu atraso e imprevisibilidade, raramente conduz a um eficiente processo." (TAYLOR e BURANELLI, p.65, tradução nossa)

O Ministério Público ocupa, portanto, um papel elementar de agência de accountability horizontal, como disposta por O’Donnell (1998). Ele possui a independência e capacidade necessária para a atuação das agências, além da legitimidade legal. A disposição, como analisada por Taylor e Buranelli (2007), é problemática: o Ministério Público carece de certas motivações para exercer seu trabalho com excelência.

Ao fazer uma analogia com a conceitualização de Lindberg (2009), percebe-se que o Ministério Público é um importante principal para a accountability política. Na verdade, chega a ser um principal com tarefas homéricas: existe um incontável número de agents passíveis de accountability pelo Ministério Público; um número também incontável de domínios e responsabilidades D supervisionadas; e para exercer suas funções possui um contingente relativamente baixo, apesar de bem instruído (TAYLOR e BURANELLI, 2007, p.64-65).

Por ser principal de grande importância, ao Ministério Público foi concedida uma série de garantias para a manutenção de um trabalho firme. De forma simétrica com a independência concedida ao Judiciário (RODRIGUES, 2008, p.47-50), o Ministério Público possui grande 
autonomia administrativa, financeira e funcional. E também de forma simétrica com os questionamentos com relação ao Judiciário, cabe perguntar se sua autonomia está adequada, uma vez que a instituição possui grande discricionariedade (KERCHE, 2007).

\subsection{O Ministério Público como agente de accountability (agent)}

Por agente de accountability, me refiro ao trabalho de Lindberg (2009). Estudar uma instituição política como o Ministério Público desta forma significa analisar a maneira como ele é fiscalizado, como se garante que ele está atuando da forma esperada e se não há abusos. Na terminologia de Lindberg, busca-se estudar o Ministério Público como agent, que devido a suas grandes responsabilidades e domínios D, deve a algum principal informar sobre sua atuação e, se for o caso, ser punido.

Como visto acima, a Carta de 1988 concedeu ao Ministério Público grande independência. De fato, por sua grande esfera de atuação e sua autonomia, o Ministério Público é freqüentemente chamado de "quarto poder". Maurício Gomes afirma que as disposições constitucionais equipararam o Ministério Público aos “demais poderes do Estado", para ele a autonomia funcional, administrativa, financeira e garantias políticas "o colocam definitivamente como órgão de defesa dos interesses sociais até contra o Estado.” (1989, p.77)

Entretanto tais garantias não deveriam significar uma falta de prestação de contas a agentes externos e nem uma falta de supervisão da atuação dos membros do Ministério Público. Em outras palavras, não deveria haver agências de accountability horizontal fiscalizando o Ministério Público? Assim como ele fiscaliza outras instituições do Estado, ele também poderia ser fiscalizado por órgãos externos.

Quanto a instrumentos diretos de fiscalização, na visão de Kerche (2007, p.261)

a conclusão seria que há total ausência de accountability e que os constituintes abriram mão de qualquer tipo de interferência sobre os rumos do Ministério Público no Brasil, ocorrendo uma abdicação por parte dos políticos em relação à instituição. As sanções diretas não ocorrem, inclusive porque não existem instrumentos para que os políticos as façam. Embora seja prevista uma fiscalização 
contábil, financeira, orçamentária, operacional e patrimonial pelo Parlamento, esta se restringe a questões de responsabilidade do Tribunal de Contas e não se traduz no acompanhamento das atividades propriamente processuais do Ministério Público.

No entanto, isso não quer dizer que o Ministério Público tem liberdade total e que pode agir desconsiderando completamente os interesses dos outros agentes do Estado. Não houve abdicação completa favorecendo a instituição, mas uma quasi-abdicação. (ibidem, p.263)

Por quasi-abdicação, Kerche entende que os dispositivos constitucionais oferecem significativa independência ao Ministério Público, mas não independência total. $\mathrm{O}$ orçamento continua sendo aprovado em última instância pelos políticos eleitos, e estes também possuem o poder da iniciativa legislativa para alterar a estrutura de um órgão do Estado. No entanto, o Ministério Público ainda está relativamente mais protegido de mudanças que outras instituições governamentais, por suas disposições estarem asseguradas constitucionalmente, e não regulamentadas por legislação ordinária.

De certa forma o Judiciário, por ser a instituição que julga os processos instaurados pelo Ministério Público, exerce certo poder de veto sobre ele. No entanto, em alguns casos, como aqueles relacionados ao direito do consumidor, ao meio ambiente e à comunidade (direitos difusos) uma resolução é atingida sem a necessidade de ida aos tribunais. Procedimentos extrajudiciais são inclusive preferidos por promotores e procuradores. (SADEK apud KERCHE, 2007, p. 265)

O controle do Judiciário também pode ser mitigado pela sua demora em responder. Como dito anteriormente, alguns membros do Ministério Público buscam a mídia para divulgar suas investigações e com isso compensar a demora e dificuldade dos processos judiciais. Mas se um tribunal considerar certo político inocente, porém a opinião pública já se encarregou de condená-lo, de que adiantou?

A indicação do procurador-geral da República pelo Presidente, aprovada por maioria do Senado, "poderia sugerir que o cargo é de confiança e, portanto, um instrumento importante de interferência dos políticos sobre o Ministério Público da União." (ibidem, p. 266) Como procuradorgeral, o indicado poderia trabalhar em afinidade com os interesses dos políticos que o levaram ao cargo, conduzindo a política institucional nesta direção. 
No entanto tal possibilidade é atenuada por dois mecanismos institucionais. Em primeiro lugar a nova Constituição inaugurou um novo sistema para a demissão do cargo de procurador-geral: anteriormente, a demissão era ad nutum, ou seja, à discrição da chefia. Pelas regras atuais, a destituição do cargo exige, além da iniciativa do Presidente da República, deliberação da maioria absoluta do Senado (art.128, parágrafo $2^{\circ}, \mathrm{CF}$ ). Tal medida pode ser politicamente custosa ao Executivo, além de mais burocrática e complexa, e caracteriza mais uma garantia para a autonomia do Ministério Público. Em outros países, o Executivo geralmente possui a discricionariedade para remoção do chefe da instituição que detém o monopólio da ação penal (KERCHE, 2005). Neste contexto, há dois principals distintos (Presidência e Senado), o que representa uma dificuldade para orientar a conduta do procurador-geral da República, uma vez que os interesses dos dois "chefes" nem sempre se coincidem.

O segundo aspecto diz respeito às características estruturais que limitam a atuação do procurador-geral como principal. Kerche aponta que (2007, p. 267):

a estrutura do Ministério Público não é tradicionalmente hierárquica, como se dá na maior parte das organizações estatais. Os procuradores do Ministério Público Federal possuem considerável autonomia diante do procurador-geral da República, assim como os promotores em relação aos procuradores-gerais de Justiça dos estados.

Inclusive a ascensão na carreira independe de uma atuação de acordo com os desejos dos superiores, pois a promoção é por antiguidade ou por decisão de órgão colegiado do Ministério Público. Como dispõe Kerche, "Esse modelo pode incentivar uma baixa previsibilidade de atuação do Ministério Público e impossibilitar a criação de uma política institucional unificada e coerente definida pelo procurador-geral." (ibidem, p.267)

O caso dos procuradores-gerais de Justiça, chefes dos Ministérios Públicos dos estados, não é muito diferente. Eles estão de fato menos suscetíveis a trabalhar em afinidade com os políticos: enquanto que para procurador-geral da República a possibilidade de recondução ao cargo é indefinida, aos procuradores-gerais dos estados ela é permitida uma única vez. No segundo mandato, há menos estímulos para agradar aqueles que o elegeram. Outro problema diz respeito aos múltiplos principals: enquanto que a nível federal existem dois (Presidência e Senado), no plano estadual são três. O Art.128, parágrafo $3^{\circ}$ da Constituição Federal dispõe que: 
Os Ministérios Públicos dos Estados e o do Distrito Federal e Territórios formarão lista tríplice dentre integrantes da carreira, na forma da lei respectiva, para escolha de seu Procurador-Geral, que será nomeado pelo Chefe do Poder Executivo, para mandato de dois anos, permitida uma recondução.

A destituição nesse caso ocorre por deliberação da Assembléia Legislativa nos estados, ou da Câmara Legislativa no caso do Distrito Federal (parágrafo $4^{\circ}$ ). Portanto, tanto Executivo, Legislativo e o próprio Ministério Público exercem influência política no procurador-geral de Justiça - em outras palavras, atuam como principals. É interessante o contraste de opiniões sobre o assunto: enquanto Kerche atenta para os problemas de múltiplos principals, que dificulta a definição de uma conduta política, o procurador Maurício Gomes sobre esse regimento discorre que "Vê-se aqui aplicada a teoria dos freios e contrapesos, pela qual se aperfeiçoa a separação de poderes garantindo-se efetivamente a independência e harmonia entre eles". (1989, p.71)

Analisando as características institucionais dispostas acima, pode-se concluir que os mecanismos conferidos a outros agentes do Estado para atuarem como principals são burocraticamente desestimulantes e não são capazes de influenciar de maneira significativa a atuação dos membros do Ministério Público. Se considerarmos que (CARVALHO e LEITÃO, 2010, p.409):

Ao se moldar uma instituição deve sempre se levar em conta o princípio madisoniano de que os homens não são anjos e não será um concurso público que irá transformá-los em anjos. Ou seja, alto grau de discricionariedade combina com mecanismos de controle e accountability, mesmo com relação a agentes nãoeleitos.

Não foram feitos muitos esforços - ou houve um forte lobby institucional (ibidem, p.403-408) - para mitigar a discricionariedade do Ministério Público. No papel de agente político, a instituição possui uma liberdade muito grande frente a outros atores, mesmo com grande leque de atribuições e instrumentos de ação (KERCHE, 2007, p.270-279). Outro aspecto que reforça a questão é que constitucionalmente o Ministério Público é considerado uma "bolha de bilhar", sem que se leve em conta a pluralidade de interesses e o caráter político que, por definição, se opõe a uma univocidade. Afinal, se todos tivessem a mesma opinião não haveria política.

Para conter a possibilidade de arbitrariedade sem controle na instituição é que surge o Conselho Nacional do Ministério Público. Ao longo da década de 90 e início dos anos 2000, os políticos debateram sobre a necessidade de uma Reforma do Judiciário, para a sociedade dispor de 
mais instrumentos de accountability perante a instituição. A relevante identidade entre Judiciário e Ministério Público - e os questionamentos sobre a autonomia de ambos - fez com que no dia 30 de dezembro de 2004 fossem criados o Conselho Nacional de Justiça e Conselho Nacional do Ministério Público, para serem instalados no ano seguinte.

\subsubsection{O Conselho Nacional do Ministério Público}

Em 2005, o Conselho Nacional do Ministério Público inicia seu funcionamento. Suas atribuições estão dispostas no Artigo 130-A da Constituição Federal:

Compete ao Conselho Nacional do Ministério Público o controle da atuação administrativa e financeira do Ministério Público e do cumprimento dos deveres funcionais de seus membros, cabendo-lhe:

I - zelar pela autonomia funcional e administrativa do Ministério Público, podendo expedir atos regulamentares, no âmbito de sua competência, ou recomendar providências;

II - zelar pela observância do art. 37 e apreciar, de ofício ou mediante provocação, a legalidade dos atos administrativos praticados por membros ou órgãos do Ministério Público da União e dos Estados, podendo desconstituí-los, revê-los ou fixar prazo para que se adotem as providências necessárias ao exato cumprimento da lei, sem prejuízo da competência dos Tribunais de Contas;

III - receber e conhecer das reclamações contra membros ou órgãos do Ministério Público da União ou dos Estados, inclusive contra seus serviços auxiliares, sem prejuízo da competência disciplinar e correicional da instituição, podendo avocar processos disciplinares em curso, determinar a remoção, a disponibilidade ou a aposentadoria com subsídios ou proventos proporcionais ao tempo de serviço e aplicar outras sanções administrativas, assegurada ampla defesa;

IV - rever, de ofício ou mediante provocação, os processos disciplinares de membros do Ministério Público da União ou dos Estados julgados há menos de um ano;

V - elaborar relatório anual, propondo as providências que julgar necessárias sobre a situação do Ministério Público no País e as atividades do Conselho, o qual deve integrar a mensagem prevista no art. 84 , XI. 
As atividades do Conselho estão focadas em duas áreas: regulamentação e controle administrativo. Através de atos regulamentares ou recomendação de providências, possibilita-se certa padronização de práticas oficiais (ou como diria Weber, racionalização), quando a lei não o faz. Entretanto, eles nunca podem tencionar substituir leis ou alterá-las. O controle externo dos Conselhos criados pela Emenda Constitucional n45 diz respeito às "diversas situações que surjam da atividade concreta dos juízes e membros do Ministério Público" (STRECK; SARLET e CLÈVE, 2005, p.22) e é nesse âmbito que estão os atos regulamentares.

$\mathrm{Na}$ dimensão do controle administrativo, ambos os Conselhos não tocam no mérito decisório de magistrados, promotores e procuradores. Limitam-se a zelar pelos princípios que norteiam o funcionalismo público (art. $37 \mathrm{CF}$ ) e coibir os possíveis abusos. Para isso dentro dos Conselhos há a Corregedoria Nacional, que atua como espécie de ouvidoria, aos quais aqueles a quem o Ministério Público e o Judiciário prestam serviços - indivíduos e grupos da sociedade podem reportar possíveis ações delituosas cometidas por membros, inclusive em serviços auxiliares. As reclamações recebidas na Corregedoria poderiam servir como o tipo de fiscalização "alarme de incêndio", que "permite que os políticos busquem modificar a atuação dos agents quando os grupos organizados, que giram na órbita daquela burocracia, fazem soar o alarme contra eventuais falhas daqueles atores estatais". (KERCHE, 2007, p.269)

No entanto, Kerche aponta que esse tipo de fiscalização encontra dificuldades no fato dos "clientes" do Ministério Público muitas vezes serem indivíduos isolados ou grupos insuficientemente organizados para ter sua voz ouvida pelos políticos. E, mesmo se ouvidos, há o problema dos fracos instrumentos de accountability no quesito punição por parte de políticos. As possíveis punições, como visto acima, são burocraticamente desestimulantes e custosas.

Por esse ângulo, a instauração do Conselho Nacional do Ministério Público não trouxe significativas melhorias para a accountability externa, pois os políticos não dispõem de instrumentos adequados para a etapa da sanção. Ou seja, se os informativos sobre o Ministério Público dispostos pelo Conselho não forem do agrado de membros Legislativo e Executivo, não haverá muitas possibilidades para tentar mudar o cenário por parte deles.

Logo a criação do Conselho não trouxe alterações significativas nos mecanismos dispostos por outros agentes estatais para atuarem como principals, apesar de uma melhora na 
dimensão informativa. Resta saber em que medida o Conselho é um principal do Ministério Público.

Pela composição do Conselho, é possível realizar algumas conjecturas (art. 130-A):

O Conselho Nacional do Ministério Público compõe-se de quatorze membros nomeados pelo Presidente da República, depois de aprovada a escolha pela maioria absoluta do Senado Federal, para um mandato de dois anos, admitida uma recondução, sendo:

I - o Procurador-Geral da República, que o preside;

II - quatro membros do Ministério Público da União, assegurada a representação de cada uma de suas carreiras;

III - três membros do Ministério Público dos Estados;

IV - dois juízes, indicados um pelo Supremo Tribunal Federal e outro pelo Superior Tribunal de Justiça;

V - dois advogados, indicados pelo Conselho Federal da Ordem dos Advogados do Brasil;

VI - dois cidadãos de notável saber jurídico e reputação ilibada, indicados um pela Câmara dos Deputados e outro pelo Senado Federal.

De catorze membros, oito (57\%) são integrantes do próprio Ministério Público. O controle externo de uma instituição é possível quando a maioria dos controladores são agentes internos? Outro aspecto interessante é que todos os conselheiros são operadores do direito, e apenas dois são indicados por agentes públicos eleitos diretamente. Como afirma Kerche, "se a idéia era uma fiscalização externa mais efetiva e cotidiana, a composição do órgão com a maioria de membros do próprio Ministério Público pode não ser suficiente para romper elementos corporativos." (2007, p.270)

O Conselho também deve escolher por votação secreta um Corregedor nacional, que constitucionalmente dispõe de três atribuições: (art. 130-A, parágrafo $3^{\circ}$ )

I - receber reclamações e denúncias, de qualquer interessado, relativas aos membros do Ministério Público e dos seus serviços auxiliares;

II - exercer funções executivas do Conselho, de inspeção e correição geral;

III - requisitar e designar membros do Ministério Público, delegando-lhes atribuições, e requisitar servidores de órgãos do Ministério Público. 
No sítio eletrônico do Conselho $^{8}$ podem ser encontradas mais atribuições da Corregedoria. Dentre elas, está: "Manter contato direto com as demais Corregedorias do Ministério Público" e "Promover reuniões periódicas com os órgãos e os membros do Ministério Público envolvidos na atividade correicional para fins de estudo, acompanhamento e apresentação de sugestões." Também à Corregedoria Nacional cabe "Determinar a autuação e o processamento dos pedidos que atendam aos requisitos de admissibilidade, com a notificação do membro ou servidor do Ministério Público citado para que apresente defesa prévia acompanhada das provas que entender pertinentes".

Pelas atribuições da Corregedoria, fica claro que ela deve atuar como principal, onde os agents são membros do Ministério Público. Todavia, ela deve ser acionada por algum "cliente" para que efeitos possam surgir. Portanto, a característica "supervisão" (TAYLOR e BURANELLI, p.62) não está tão disposta ao Conselho. No entanto Rodrigues considera que no Conselho Nacional de Justiça a característica está presente, devido à capacidade deste de expedir recomendações e atos regulamentares e poder pautar o planejamento estratégico do Judiciário (2008, p.80), e o Conselho Nacional do Ministério Público possui a mesma atribuição. Fica a questão se esta regulamentação é útil para coibir possíveis delitos.

Em uma pesquisa realizada em 2010, coordenada pelas professoras do Instituto de Ciência Política da Universidade de Brasília, Doutoras Graziela Teixeira e Marilde Menezes, foram entrevistados os quinze membros do Conselho que estavam no cargo naquele ano. No questionário constavam 21 perguntas relacionadas ao Ministério Público e ao Conselho. Algumas respostas foram interessantes para a tentativa de compreender a cultura organizacional.

Ao serem questionados se "O CNMP deveria controlar também a atividade-fim do Ministério Público no tocante aos procedimentos preparatórios e investigatórios", oitenta por cento discordaram de tal afirmação. A maioria dos membros do Conselho, portanto, consideram que o controle deve ser apenas administrativo, sem entrar no âmbito do mérito das decisões de promotores e procuradores.

Sessenta por cento concordam ou concordam parcialmente que "o Ministério Público deve agir com plena liberdade em sua missão, podendo fazer ou deixar de fazer em quaisquer

\footnotetext{
${ }^{8}$ http://www.cnmp.gov.br
} 
questões relativas a sua atribuição." Uma grande maioria (80\%) não considera que seria mais legítimo se todos pudessem ser votados para a escolha do Corregedor-Geral. No regimento atual (art.30), apenas os membros do Ministério Público podem ser candidatos ao cargo. De quinze membros, treze concordam ou concordam parcialmente que a estrutura atual do Conselho condiz com suas finalidades.

De um modo geral, a pesquisa indicou que os membros do Conselho são resistentes à mudança, e estão satisfeitos com as atuais atribuições do órgão. Eles reconhecem que o Ministério Público é tradicionalmente um órgão resiliente e não demonstram inclinações para reformas. As respostas dos entrevistados também sugerem que eles prezam muito pela autonomia do Ministério Público, e pela independência funcional de seus membros. Mudanças que pudessem mitigar essas garantias foram em geral descartadas.

A pesquisa tinha a intenção de continuar a aplicação dos questionários. Os próximos entrevistados seriam os Procuradores da República no Distrito Federal. Dados sobre a opinião de membros do Ministério Público externos ao Conselho seriam bastante interessantes. No entanto, a falta de receptividade dos procuradores dificultou muito o trabalho: muitos deles não foram encontrados ou se recusaram a responder a pesquisa, que obteve um volume muito baixo de respostas (dos 26 procuradores, menos da metade respondeu ao questionário). 


\section{Conclusão}

O principal objetivo deste trabalho era analisar o Ministério Público quanto à accountability horizontal. Pelos tratamentos teóricos dados ao conceito, principalmente por Guillermo O’Donnell (1998) e Staffan Lindberg (2009), isso significou estudar a estrutura de agências estatais relacionadas pela fiscalização do exercício do poder estatal. O Ministério Público está inserido nesta estrutura, possuindo um papel importante de agente fiscalizador. Constatou-se que o Ministério Público é uma agência de accountability horizontal nos termos dispostos por O’Donnell, pois parte de sua atuação é no sentido de "realizar ações, que vão desde a supervisão de rotina a sanções legais ou até o impeachment contra ações ou emissões de outros agentes ou agências do Estado que possam ser qualificadas como delituosas.” (1998, p.40) Para tal finalidade, a instituição possui diversos instrumentos de ação, além de uma ampla área de atuação - ou discricionariedade (KERCHE, 2007).

No entanto, a capacidade do Ministério Público fiscalizar outras instituições estatais não é recíproca. Como visto, a Constituição de 1988 conferiu grande autonomia ao órgão, sendo que mecanismos diretos para que agentes externos atuem como principals são fracos. Na mesma direção tomada pelo Judiciário, os membros do Ministério Público possuem um leque de garantias que garantem sua independência, além de autonomia administrativa e financeira. Até 2005, reclamações quanto à atuação de promotores e procuradores eram tratadas internamente. Se há qualquer caráter corporativista na instituição, a accountability interna é bastante difícil. Desta forma, os 
questionamentos de Santiso (apud RODRIGUES, p.50) quanto à independência do Judiciário são cabíveis ao Ministério Público.

Portanto, no âmbito da accountability a instituição assume uma faceta incomum: ao mesmo tempo em que possui grandes poderes para fiscalizar as ações do Estado, ou nas palavras de Kerche, "amplo leque de atribuições e instrumentos de ação" (2007, p.270), estes não vêm acompanhados de medidas para os promotores serem passíveis de accountability por agentes externos. Houve uma quasi-abdicação a favor do Ministério Público: foi concedida ampla independência, e as ferramentas de controle externo são complicadas. É bastante trabalhoso para políticos tentar uma mudança nas conduções do órgão, pois os mecanismos são muito difusos. A possibilidade de escolha do Procurador-Geral da República não facilita, pois sua atuação é limitada.

Uma medida que poderia contribuir para o controle externo foi a criação do Conselho Nacional do Ministério Público. No entanto, a composição do Conselho gera suspeitas: a maioria dos membros é pertencente ao órgão, e todos são operadores do direito. Para o cargo de CorregedorGeral, apenas são elegíveis membros do Ministério Público. A extensão da atuação do Conselho não ajuda, pois suas competências não atingem o mérito das decisões dos promotores e procuradores. A maioria dos Conselheiros é inclusive favorável à manutenção da independência funcional e da discricionariedade. Considerando o caráter político recentemente atribuído à atuação do Ministério Público (ARANTES, 1999), talvez fosse razoável a existência de um controle externo mais rígido.

É importante frisar que os dados analisados não permitem afirmar se o Ministério Público é ou não uma instituição corporativista. Para a aquisição de dados empíricos, as ferramentas são poucas, e conflitos de interesse com o Ministério Público são possíveis, como ocorreu durante a pesquisa realizada em 2010. No entanto, a abordagem neoinstitucionalista permite fazer conjecturas razoáveis, e pelos paradigmas políticos modernos, a parte legal é extremamente importante.

Dado o foco pelas instituições formais do trabalho, infere-se que como agentes políticos, promotores e procuradores são privilegiados, pois seus grandes poderes não acarretam grandes responsabilidades a agentes externos, como ocorre normalmente. No plano da accountability horizontal, o Ministério Público ocupa um terreno para poucos. Uma tentativa de mudança é bastante complexa no cenário brasileiro, se considerarmos os problemas históricos 
(CAMPOS, 1990; PINHO e SACRAMENTO, 2009) envolvendo os mais importantes principals da accountability política: os cidadãos.

\section{Referências Bibliográficas}

ARANTES, Rogério. Direito e Política: O Ministério Público e a Defesa dos Direitos Coletivos. Revista Brasileira de Ciências Sociais, vol. 14, n 39, p.83-102, 2009.

CAMPOS, Anna Maria. Accountability: quando poderemos traduzi-la para o português? Revista de Administração Pública, Rio de Janeiro, fev./abr. 1990.

CARVALHO, Ernani; LEITÃO, Natália. O Novo Desenho Institucional do Ministério Público e o Processo de Judicialização da Política. Revista Direito GV. São Paulo, v.6, n.2, p. 399-422, 2010.

CASA CIVIL DA PRESIDÊNCIA DA REPÚBLICA. Dispõe acervo com toda a legislação federal brasileira, bem como acervo histórico que inclui Constituições anteriores. Disponível em: http://www4.planalto.gov.br/legislacao Acesso em: 02 nov. 2011.

CONSELHO NACIONAL DO MINISTÉRIO PÚBLICO. Divulga informações sobre a atuação do Conselho. Disponível em: http://www.cnmp.gov.br/portal/index.php Acesso em: 03 nov. 2011.

DAHL, Robert. Democracy and its Critics, New Haven, Yale University Press, 1989. 
DOMINGO, Pilar. Judicial Independence and Judicial Reform in Latin America. In DIAMOND, Larry; PLATTNER, Marc. F.; SCHEDLER, Andreas. The Self Restraining State: power and Accountability in new democracies. Lynne Rienner Publishers. Boulder: 1999

FOLHA DE SÃO PAULO. 'Quem faz a faxina é a lógica mafiosa', diz cientista político. Disponível em: http://www1.folha.uol.com.br/poder/998789-quem-faz-a-faxina-e-a-logicamafiosa-diz-cientista-politico.shtml . Acesso em: 10 de nov. de 2011.

GOMES, Maurício Augusto. Ministério Público na Constituição de 1988: breves anotações. Justitia, São Paulo, v. 51, n. 145, p. 64-78, jan./mar. 1989. Disponível em: http://bdjur.stj.jus.br/dspace/handle/2011/25675. Acesso em: 18 nov. 2011

GONÇALVES, Alcindo. O conceito de governança. XIV Encontro do Conpedi, 2005.

KERCHE, Fábio. Agências Responsáveis pela Ação Penal: Um Estudo Comparativo. Revista Brasileira de Ciências Criminais, nº55, p. 127-152, 2005.

KERCHE, Fábio. Autonomia e Discricionariedade do Ministério Público no Brasil. Dados - Revista de Ciências Sociais, Rio de Janeiro, v.50, n.2, p. 259-279, 2007.

LINDBERG, Staffan I. Accountability: the core concept and its subtypes. APPP Working Paper, No. 1, 2009, Londres.

MAINWARING, Scott. Introduction: Democratic Accountability in Latin America. In MAINWARING, Scott; WELNA, Christopher. Democratic accountability in Latin America. New York: Oxford University Press, 2003.

O’DONNELL, Guillermo. Democracia Delegativa. Disponível em: http://www.journalofdemocracyenespanol.cl/pdf/odonnell.pdf Originalmente publicado em: Journal of Democracy, Vol. 5, No. 1, January 1994: 55-69. 
O'DONNEL, Guillermo. Accountability horizontal e novas poliarquias. Lua Nova, n.44, 1998, p. 27-52.

PERUZZOTTI, Enrique; SMULOVITZ, Catalina. Societal and Horizontal Controls: Two Cases of a Fruitful Relationship. In MAINWARING, Scott; WELNA, Christopher. Democratic accountability in Latin America. New York: Oxford University Press, 2003.

PINHO, José Antonio Gomes de; SACRAMENTO, Ana Rita Silva. Accountability: já podemos traduzi-la para o português? Rev. Adm. Pública, v. 43, n.6, Rio de Janeiro Nov./Dez. 2009, p. 1343-1368.

RODRIGUES, Leandro do Nascimento. O Conselho Nacional de Justiça como instrumento de accountability horizontal: análise do período 2005-2007. Dissertação (mestrado em Ciência Política) - Instituto de Ciência Política, Universidade de Brasília, Brasília, 2008.

SCHEDLER, Andreas. Conceptualizing Accountability. In DIAMOND, Larry; PLATTNER, Marc. F.; SCHEDLER, Andreas. The Self Restraining State: power and Accountability in new democracies. Lynne Rienner Publishers. Boulder: 1999

SCHMITTER, Philippe C. The Limits of Horizontal Accountability. In DIAMOND, Larry; PLATTNER, Marc. F.; SCHEDLER, Andreas. The Self Restraining State: power and Accountability in new democracies. Lynne Rienner Publishers. Boulder: 1999

SKLAR, Richard L. Democracy and Constitutionalism. In DIAMOND, Larry; PLATTNER, Marc. F.; SCHEDLER, Andreas. The Self Restraining State: power and Accountability in new democracies. Lynne Rienner Publishers. Boulder: 1999

STRECK, Lenio Luiz; SARLET, Ingo Wolfgang; CLÈVE, Clemerson Merlin. Os Limites Constitucionais das Resoluções do Conselho Nacional de Justiça (CNJ) e Conselho Nacional do Ministério Público (CNMP). Revista da Esmesc, v.12, n.18, p. 15-24, 2005.

TAYLOR, Matthew; BURANELLI, Vinícius. Ending Up in Pizza: Accountability as a Problem of Institutional Arrangement in Brazil. Latin American Politics \& Society, v.49, N.1, Spring 2007, p. 59-87 
